\title{
Investigation on the impacts of COVID-19 quarantine on society and environment: Preventive measures and supportive technologies
}

\author{
Santhosh Kumar Kumaravel ${ }^{1} \cdot$ Ranjith Kumar Subramani $^{1} \cdot$ Tharun Kumar Jayaraj Sivakumar $^{1}$. \\ Rajvikram Madurai Elavarasan ${ }^{1,2} \mathbb{D}$. Ajayragavan Manavalanagar Vetrichelvan ${ }^{1}$. Annapurna Annam ${ }^{1}$. \\ Umashankar Subramaniam ${ }^{3}$
}

Received: 10 June 2020 / Accepted: 5 August 2020 / Published online: 17 August 2020

(c) King Abdulaziz City for Science and Technology 2020

\begin{abstract}
The present outbreak of the novel coronavirus SARS-CoV-2, epicentered in China in December 2019, has spread to many other countries. The entire humanity has a vital responsibility to tackle this pandemic and the technologies are being helpful to them to a greater extent. The purpose of the work is to precisely bring scientific and general awareness to the people all around the world who are currently fighting the war against COVID-19. It's visible that the number of people infected is increasing day by day and the medical community is tirelessly working to maintain the situation under control. Other than the negative effects caused by COVID-19, it is also equally important for the public to understand some of the positive impacts it has directly or indirectly given to society. This work emphasizes the various impacts that are created on society as well as the environment. As a special additive, some important key areas are highlighted namely, how the modernized technologies are aiding the people during the period of social distancing. Some effective technological implications carried out by both information technology and educational institutions are highlighted. There are also several steps taken by the state government and central government in each country in adopting the complete lockdown rule. These steps are taken primarily to prevent the people from COVID-19 impact. Moreover, the teachings we need to learn from the quarantine situation created to prevent further spread of this global pandemic is discussed in brief and the importance of carrying them to the future. Finally, the paper also elucidates the general preventive measures that have to be taken to prevent this deadly coronavirus, and the role of technology in this pandemic situation has also been discussed.
\end{abstract}

Keywords COVID-19 $\cdot$ Quarantine $\cdot$ Technologies $\cdot$ Social impacts $\cdot$ Environmental benefits $\cdot$ Preventive measures

Electronic supplementary material The online version of this article (https://doi.org/10.1007/s13205-020-02382-3) contains supplementary material, which is available to authorized users.

Rajvikram Madurai Elavarasan rajvikram787@gmail.com

Santhosh Kumar Kumaravel santhosh.k0705@gmail.com

Ranjith Kumar Subramani vsranjith082000@gmail.com

Tharun Kumar Jayaraj Sivakumar jstharunkumar262@gmail.com

Ajayragavan Manavalanagar Vetrichelvan ajayragavanmv@gmail.com

Annapurna Annam annamannapurna748@gmail.com
Umashankar Subramaniam shankarums@gmail.com

1 Department of Electrical and Electronics Engineering, Sri Venkateswara College of Engineering, Chennai, Tamil Nadu 602117, India

2 Electrical and Automotive Parts Manufacturing Unit, AA Industries, Chennai, Tamil Nadu 600123, India

3 Renewable Energy Laboratory, Faculty of Engineering, Prince Sultan University, Riyadh 11586, Saudi Arabia 


\section{Introduction}

An unprecedented outbreak of mysterious etiology pneumonia, which occurred in December 2019, has taken the whole world to a state of sorrow and worry about the future. The novel coronavirus (COVID-19) is a respiratory illness and its outbreak primarily originated from Wuhan, China. The epidemic is found to be caused by a zoonotic transmission event associated with a wide seafood market and soon became transmission from human to human (Zhou et al. 2020). Mostly the virus affects animals only, but the COVID-19 virus is able to mutate into new forms that are immune to the vaccine. Despite various efforts taken by every country like global containment, travel restrictions, and treating the infected person, the incidence of COVID-19 continues to rise at a tremendous rate.

At the same time, the lockdown has also made some impacts on human society such as negative psychological effects due to quarantine, loss in the economy of the world. But there are also positive aspects like reduction in pollution due to less movement of vehicles and closure of many industries. COVID-19 is identical to coronavirus with Severe Acute Respiratory Syndrome (SARS) and coronavirus with Middle East Respiratory Syndrome (MERS). This is also known as Coronavirus 2 (SARS-CoV-2) Severe Acute Respiratory Syndrome pneumonia.

It's confirmed that the SARS-CoV-2 (Fig. 1) originated by nature itself by comparing the available genome of the coronavirus strains said by Kristia Andersen, Ph.D., an Associate Professor of immunology and microbiology at Scripps Research (Science Daily 2020a).

Coronavirus is a big family of severe respiratory illness, first it was found in 2003 at China as SARS and its second

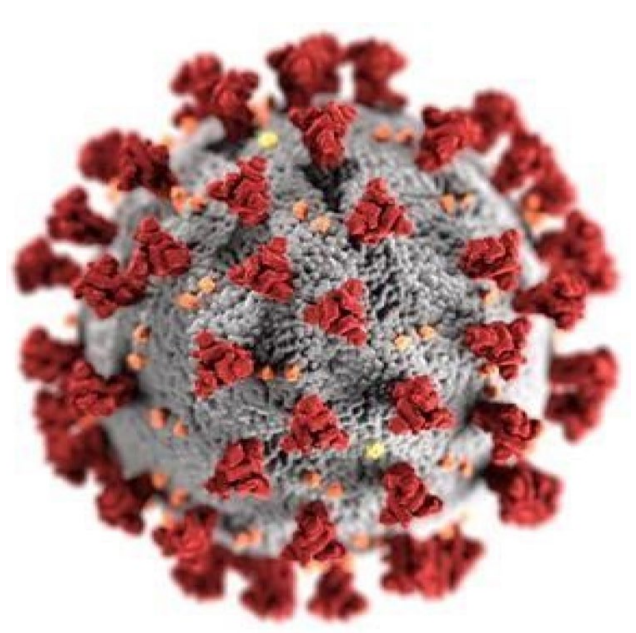

Fig. 1 Coronavirus with spike protein (Centre for Disease Control and Prevention 2020a) outbreak occurred in 2012 in Saudi Arabia as MERS (Science Daily 2020a).

The coronavirus with spike protein-RBD (Receptor Binding Domain) portion is the important part of the virus that has been evolved and binds to the cells and then cleaves the site of contact where the virus enters the human cells (Science Daily 2020a).

The articles revealed that the COVID-19 is a group of beta-coronavirus and this is mutated from bat coronavirus HKU9-1 which is the ancestor of COVID-19. This mutant virus interacts strongly with the human ACE2 receptor. The researchers state that the SARS-CoV-2 shares less than $80 \%$ nucleotide identity and has $89.10 \%$ similarity genes of the previous SARS-CoV (Qamar et al. 2020). The transmission of SARS-CoV-2 is presented as in (Fig. 2).

The genome of SARS-CoV-2 is $96.2 \%$ similar to the bat CoV RaTG13 and shares its identity from SARS-CoV (Guo et al. 2020).

It is known that the main cause of this virus has started from bats and the virus is mutated to affect the humans and it is identified that there are six coronaviruses which affect the human body and some of them are $\alpha-\mathrm{CoVs} \mathrm{HCoV}-229 \mathrm{E}$ and HCoV-NL63, which are of low pathogenicity and cause mild respiratory symptoms. The COVID-19 is a respiratory disease that spreads at a maximum rate through droplets of the infected people through the air (World Health Organisation 2020a). The coronavirus is mutant by the previous process; it has been continuously spreading between the humans, rapidly through many modes of transmission they are as follows:

- Cough or sneeze by the infected person.

- Through close contact with the victims by touching the nose, eyes, and mouth.

- The transmission of droplets occurs within $1 \mathrm{~m}$.

- The transmission can also happen by indirect means such as handling the instruments of the infected person, for example, stethoscope, thermometer (World Health Organisation 2020a).

The affected persons were observed with common symptoms like cough, fever and in addition to it, some were noticed by muscle soreness, headache, dyspnea, and fatigue. Thoracic radiology and CT (Computed Tomography) are the best evaluations of the infection COVID-19 (Bernheim et al. 2020). Also, most of the positive cases are asymptomatic, they are not aware that they are carrying the virus to spread it on.

The world statistics of infected cases increased to $14,460,554$, total deaths climbed to $6,05,735$, and recovered cases were $8,644,943$ by 19 th July 2020 (Worldometers 2020a). In India, the total number of cases was $1,081,477$, death cases were 26,873 and the recovered cases were 
Fig. 2 Mutation and Transmission of SARS-CoV-2 (Guo et al. 2020)

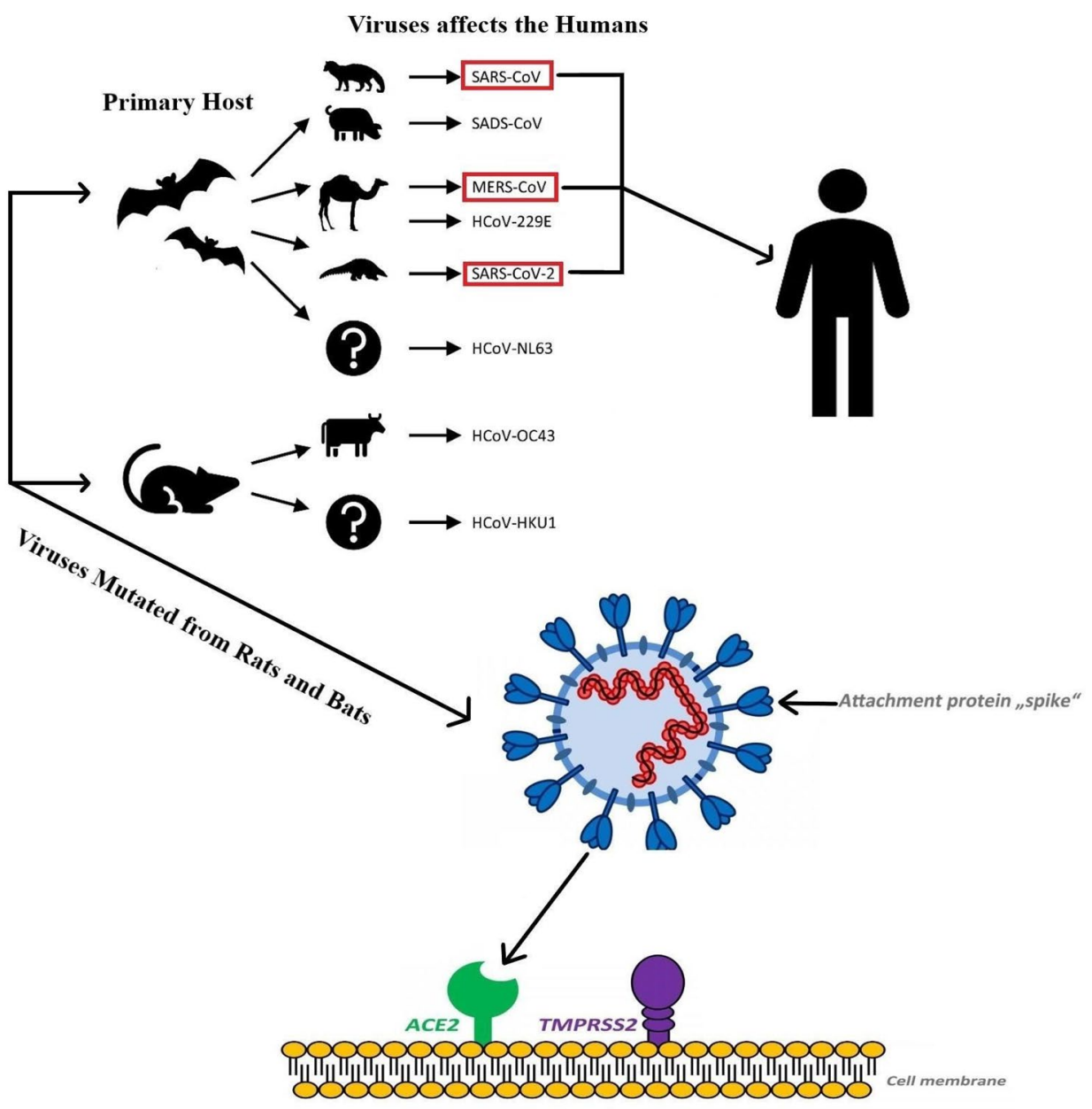

Host cell
$6,80,594$ as on July 19th 2020 (Worldometers, 2020a). The fatality rate on July 19th, 2020 was estimated to be $6.18 \%$ and it is calculated by (Total deaths/(Death + Active cases)) (Qamar et al. 2020).
The observed spread of COVID-19 is more rapid than the calculated values. The number of death cases all over the world increased about 10 times from March 10th till March 30 th from 4000 deaths to 40,000 death cases(see Fig. 3).
Fig. 3 Total no of death cases worldwide from March 10th to 30th (2020) due to COVID-19 (Worldometers 2020a)

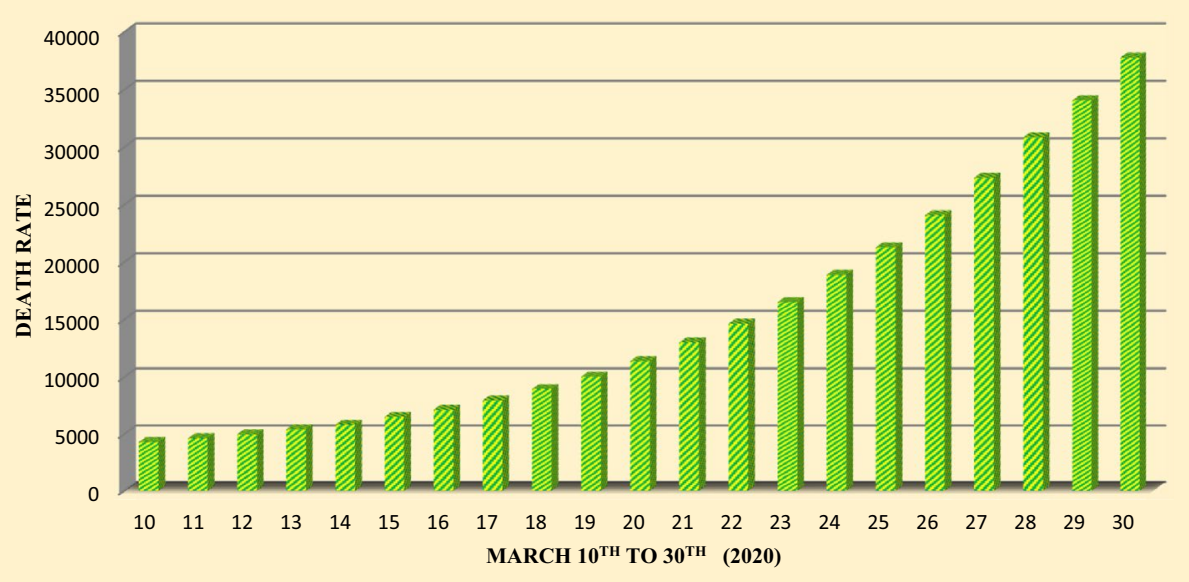

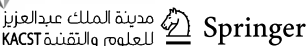


COVID-19 is a deadly disease that had no mercy on the pregnant women and even the infants inside the womb of the mothers during this pandemic. The WHO (World Health Organisation) has said that the COVID-19 affected pregnant women may die due to the infection and may spread the disease directly to the foetus and neonate. After testing the affected women who gave birth to infants, the reports state that the babies were healthy and the women were tested negative for the virus after various effective treatments (Chen et al. 2020).

The infected patients were given chloroquine phosphate to block the COVID-19 infection in low micromolar concentrations. China has tested the safety and efficacy of the chloroquine that can be used to treat COVID-19 in ten hospitals (Gao et al. 2020). The reproductive rate of COVID-19 is ranging from 1.5 to 6.5 and the average reproductive rate is 3.3 and the estimates were calculated by different personnel in different methods (Liu et al. 2020a, b) and in India, the reproduction rate of coronavirus is estimated to be 1.36 (India's COVID-19 RO value 2020). The purpose of this review is to convey the impacts on society due to the pandemic and also how to tackle this pandemic situation with the available technologies. This review shares the knowledge about the technologies that help out the industrialists, students, and doctors to fight against and run the routine life even during the lockdown. This review would also elucidate the environmental impacts that changed the world during the quarantine of the people and the preventive measures taken by the governments for the safety of the people in the world.

\section{Methodology}

In this review, the knowledge regarding the importance of quarantine and social distancing is gathered first. Statistics obtained from WHO and Worldometers is used for this review to demonstrate the quarantine effect. Then, it discusses the social nature of the disease. Statistics on the fatality incidence derived from standard research articles have also been used here. Also, the environmental effects related to the epidemic were discussed in a detailed manner. Data on the condition of air quality and bird status during the lockdown scenario is obtained from online reports and journal articles. The preventive measures for COVID-19 were also discussed. Data is also obtained based on the equipment used during the lockdown process. The knowledge obtained from academic or grey literatures were helpful to carry out this comprehensive analysis. A keyword search based method was used to collect the information along with a structured process of sorting the data. In the beginning, the keywords are made to be determined through detailed discussions. The keywords used for searching the data are COVID-19, Environmental impacts, technologies, pollution, and quarantine. The academic literatures discussed in this work here comprises of regular papers and conferences while the grey literatures discussed here contain web sources and professional studies. This analysis took Google Scholar, Scopus, and Scopus Indexed Extended as the most important research sites for framing the important sections of the work. When gathering the data and details, we ensured that only the peer-reviewed publications and online sites to be referred to.

For this review, about 270 articles and 110 official web resources were studied. The 270 articles were further reviewed to identify the most suitable papers for this analysis. Finally, 75 references from scholarly journals and 61 references from Web resources, a total of 136 references found to be the most suitable for this work, and those were included in this review analysis. When reviewing the relevant papers, a manual procedure is followed to determine the appropriateness of the papers for this study. The systematic framework for data collection adopted in this review paper is shown in (Fig. 4).

\section{Safety measures announced by WHO}

The spread of COVID-19 disease was announced by the World Health Organization (WHO) as a public health emergency of international concern on 30th January 2020 (World Health Organisation 2020b). There are currently no appropriate treatments and vaccines for this virus (Wilder-Smith and Freedman 2020). Also, evidence shows that much of the human to human transmission occurs during COVID-19's asymptomatic incubation interval, which will be approximately between 2 and 10 days (Rothe et al. 2020; Sohrabi et al. 2020). Therefore we rely entirely on public health strategies such as quarantine to restrict the spread of this respiratory disease.

Quarantine essentially involves isolating or limiting the mobility of people who have come from other countries or have been exposed to this infectious disease. In this scenario, COVID-19 infected persons are isolated from non-infected persons and this isolation usually takes place in the hospital. By quarantine, we can prevent the human-to-human spread of disease to break the chain of transmission (Wilder-Smith and Freedman 2020). Quarantine facilities must be provided to infected persons who do not have an appropriate homely environment (Cetron and Landwirth 2005). But the infected patients would also be able to transmit the disease to another person before the symptoms appear to them. The incubation time for the COVID-19 has a median of 5 days (Li et al. 2020). So quarantine is often too late to effectively stop the transmission and control this influenza pandemic (WilderSmith and Freedman 2020). 
Fig. 4 A systematic framework for the study
Data Search Progress

Various Search Engines like Google Scholar, Scopus\& Web resources like WHO(World Health Organization) were referred.
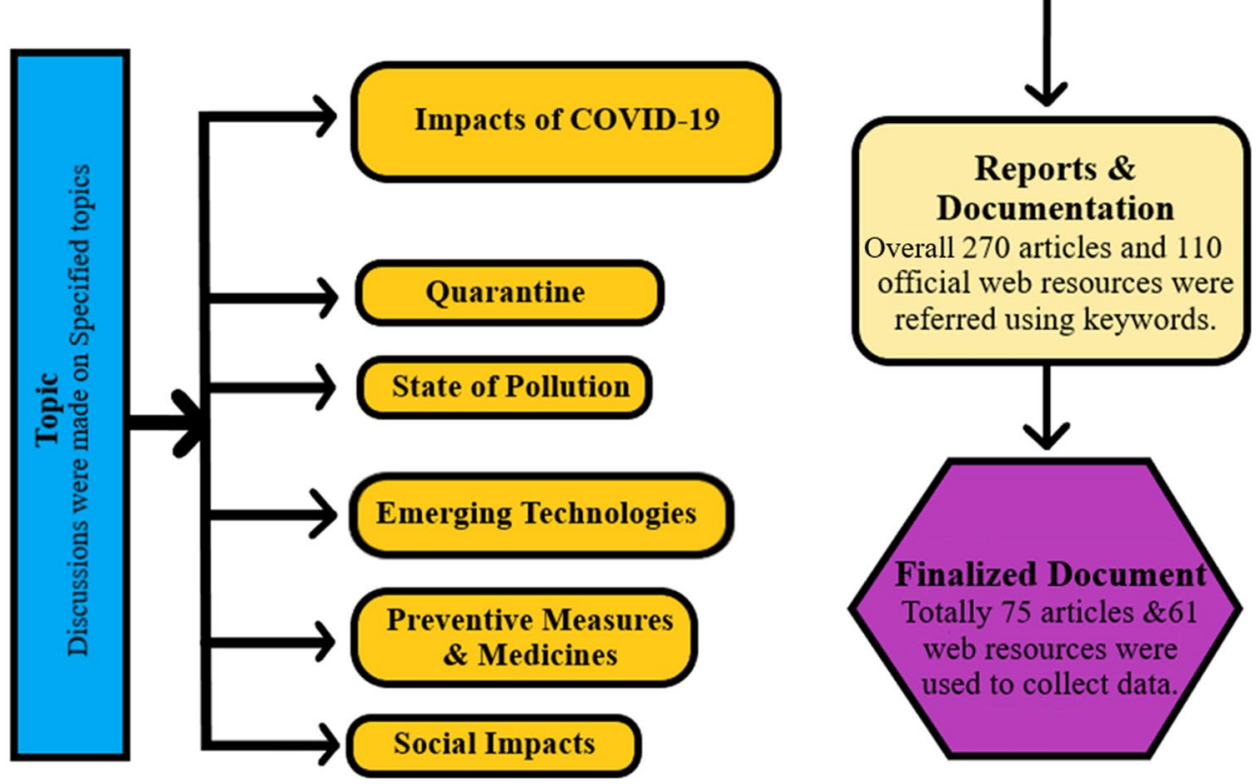

Thus, it remains unknown when the transmissibility attains its peak and how frequently pre-symptomatic cases get transformed into secondary cases. Quarantine was implemented successfully to halt the transmission during the SARS epidemic in 2003 (Goh and Chew 2006). It is one of the important steps in this pandemic disease plan. The quarantine can be done to an individual or at the group level and usually, it involves restriction to the home or a particular area. During the quarantine period, all the persons should be monitored regularly for the occurrence of any symptoms. If any symptoms occur, the infected individual must be immediately isolated in a designated place with all essential treating equipment.

By quarantining, the detection of cases becomes easier, so that contacts can be listed and traced out within a short period of time frame (Wilder-Smith and Freedman 2020). Also, quarantine includes the following benefits:

- The isolation of persons prone to reported cases will avoid a large proportion of diseases and deaths relative to those without control.

- There was little impact of quarantining travelers from a country with a reported epidemic to prevent infection and death.

- In addition, the incorporation of lockdown with other treatment and prevention measures such as school closures, travel restrictions, and social distancing has had a greater impact on spread prevention, cases requiring critical care beds, and deaths compared with quarantine alone.

So in controlling the COVID-19 outbreak, more systematic and early implementation of preventive and control measures may be more successful (Science Daily 2020b). After an effective lockdown of 2 months, the cases in China were reduced. This can be clearly viewed in Fig. 5 .

It gives a clear overview of the COVID-19 attack and how china resolved its pandemic situation. When COVID-19 cases are increasing rapidly all over the world, China had got slowly relieved from this infectious disease with its severe methodologies and treatments. This also shows the effect of massive lockdown in Mainland China. Chinese health

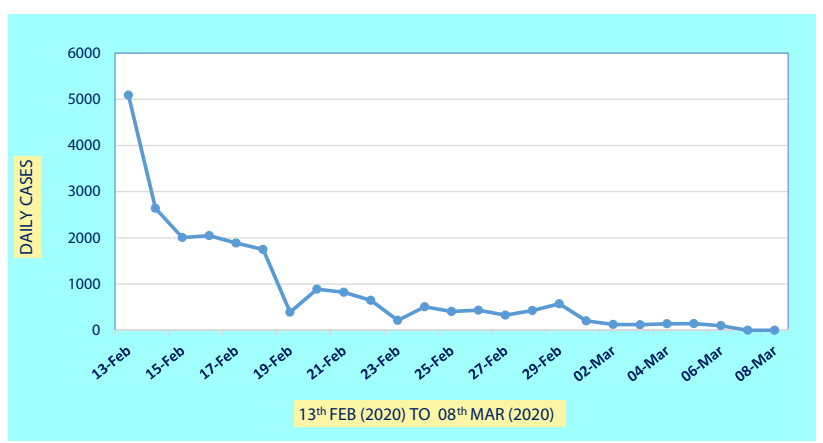

Fig. 5 Daily new cases in China from 13th Feb (2020) to 08th Mar (2020) (Worldometers 2020b) 
authorities have declared that the country had passed the peak of coronavirus outbreak on March 12th, 2020 (Impact of lockdown in China 2020).

\section{Impacts of social distancing and quarantine}

Another component to prevent transmission is 'social distancing'. This must be introduced to minimize people-topeople communication in a larger population, where individuals may be contagious but have not yet been recognized as an infected person and therefore not isolated. So social distancing of people will effectively reduce the transmission of this kind of infectious disease (Wilder-Smith and Freedman 2020). This involves avoiding unnecessary travel and social gatherings. There must always be a $2 \mathrm{~m}$ gap between people in public, independent of viral transmission (Social distancing in UK 2020). Social distancing is useful where community spread is suspected to have occurred, but where the relationship between the infected persons are uncertain and restrictions imposed only on individuals known to be exposed are considered inadequate to prevent further disease transmission (Centres for Disease Control and Prevention 2005).

Social distancing includes closure of schools or office buildings, public markets, and the cancellation of gatherings. Community-wide isolation is an initiative extended to the entire city, town or area to restrict human interactions, except for limited interactions to ensure that vital resources reach human beings. In the absence of medicinal drugs for this COVID-19 disease, the only solution is that by reducing the contact of affected people and the things used by affected people are to be totally avoided (Lewnard and Lo 2020). But implementing community-wide containment is far more complex because it involves a large number of people (Rothe et al. 2020).

It is important to use social media wisely during community-wide containment, which provides us with an opportunity to communicate the reasons for quarantine, to provide realistic advice, to avoid misinformation and getting panic. The implementation of the above mentioned public health initiatives also includes cooperation with law enforcement officials at local and state level, and it involves checkpoints and may need legal penalties if quarantine violations occur (Rothe et al. 2020). A community-wide containment is currently happening in America.

Quarantine is one of the unpleasant experiences for those who undergo it. Since quarantine includes separation from loved ones, loss of rights, confusion about the status of disease and boredom can have drastic effects (Brooks et al. 2020). This quarantine period can extend for an unpredictable long time. The possibility of psychological and mental problems increases due to quarantine (Xiao 2020).
The psychological negative effects include symptoms of post-traumatic stress, uncertainty, irritation, disappointment, insufficient knowledge, financial loss, and stigma. Studies show that post-traumatic stress in children who are quarantined is found to be four times higher than children who were not quarantined (Brooks et al. 2020). Many who are quarantined often experience a great degree of psychological distress and signs of disease.

Also due to lockdown in several countries across the world, the production of several essential commodities has been decreased. Consumer goods companies are facing various problems like the absence of labour, stranded trucks, and permissions for manufacturing products (Drop in production of essential goods 2020). The government has taken several measures to make the people stress-free. They are arranging the markets to nearby places. They are allocating funds to the poor people who are depending on money for food. They are taking several actions to make this quarantine not affect people's minds.

\section{Social aspects}

Throughout the outbreak of communicable diseases such as COVID-19, the limitations placed on daily behaviours as part of social distancing requirements to avoid the disease spread. The immediate response should include maintaining community shelters and community kitchens, supplying other relief supplies, stressing the need for social isolation, reporting the cases of infected people, and adhering to guidelines for treating these cases.

\section{Constraints in living alone and together}

It is significant to remember that isolation doesn't just freeze your brain with boredom. When people like those kept in solitary confinement, know their sentence is nearly up, their mood lifts again in anticipation. Those who experience social isolation because of COVID-19 can no longer get it. Open, clear, and reliable connectivity is what governments and organizations should achieve the most (Prem et al. 2020).

Protect yourself, and help other people. Helping others in their time of need will benefit both the individual who receives assistance and the helper. Managing your mental health, psychological, and social well-being during this period is just as essential as managing your physical health. Keep regular routines and schedules including regular exercising, cleaning, daily chores, singing, painting or other activities. Individual approach to each other can cause significant social disruption, it is necessary to know the degree of intervention which is required to minimize transmission and the burden of disease (Lewnard and Lo 2020). 
People who are living together can share many ideas to prevent this disease and also they can care for each other during this quarantine. At the same time, they should also take care of elderly people. In joint families, people will share the financial burden during this situation. They can also play with the children and always keep them engaged without feeling their loneliness.

People must be sanitized and should maintain hygiene by periodically washing their hands with soap and water for at least $20 \mathrm{~s}$. Ensure that your home and workplaces are regularly cleaned and sprayed with a disinfectant, with particular attention to electronic devices. There is currently no vaccine or antiviral drug for coronavirus in humans and animals. So it is important to be healthy during the 2019-nCoV quarantine period ( $\mathrm{Lu}$ 2020).

Symptoms of prodromal 2019-nCoV infection include nausea, dry cough and malaise are non-specific (Wang et al. 2020a, b, c). Through not exchanging personal things like food, water bottles, and utensils. Families can implement these improvements now. People can also use a separate room in your home that can be used to isolate the affected member from the safer ones. Affected people must use a separate bathroom.

In case your caretaker is sick, It is important to have the one who is really very healthy. Caregivers and their care recipients will be required to work closely and also ensure that they will not be affected by COVID-19. The caregiver will monitor the situation and regularly inquire about the wellbeing of the other tenants (Rocklöv and Sjödin 2020).

\section{Socializing via internet}

The outbreak is predicted to spread among larger sections of the society than the 2015 MERS-CoV (Yoo 2019). In this period people must utilize their time to gain knowledge by reading books via the internet.

Because of the coronavirus outbreak, the technology and industry have become their new best friend for people hunkering down, with a number of lifestyle options that make "social distancing" easier. Many of them wish to avoid crowds; they can have restaurant meals delivered, socialize online with friends, and work remotely. Lifestyle approaches inspired by the latest technologies to gain momentum as more people are motivated to work from home, as more conferences and events are cancelled. Many online streaming platforms have gained more users, as people are feeling very bored during this quarantine (Increase of online usage 2020). Internet usage has been increased; more people are using mobile phones to watch the news as it is very handy and portable.

To make this quarantine useful online classes were launched, which has let students learn from home and gain information. Nowadays, children are great at surfing and browsing the data. They are learning to play games and handle mobile phones at a younger age. This will be useful if they are acquiring knowledge but at the same time, many inappropriate content can misguide their path. So parents must watch their kid's daily activities (Web safety for kids 2018). They love to play online games because they cannot play outside during this quarantine.

Children can use the same internet for their self-development. Various videos are available on the internet platform to develop their skills (Omar et al. 2014). The internet is a blessing to the present generation as it was not available to the previous generations. It is based on how people are using the internet whether it is to be treated as a blessing or curse. The same internet is considered as a blessing in disguise as it helps people. Without the internet, people will get mentally weakened by facing the four walls during this quarantine.

As a result of the COVID-19 calamity, the trend in social media has grown, with more people going online to remain linked to families, friends, and colleagues. Recent research from Kantar's insights and advisory company shows just how many advantages those applications gain. According to a survey conducted between 14 and 24th March 2020 with more than 25,000 customers in 30 markets, WhatsApp is the social media application that earned huge attraction from the COVID-19 perspective (Rapid increase in web usage 2020). People are continuously using WhatsApp during this quarantine. As people are required to communicate with their relatives who are in distant places they are using different kinds of communication mediums. Its handling capacity has risen from an initial $27 \%$ rise in the earlier days of the pandemic to $41 \%$ in the mid-phase. WhatsApp handling has increased by $51 \%$ for countries now in the later phase of the pandemic (Rapid increase in web usage 2020).

\section{Factors affecting fatality rate}

Fatality rates were calculated by dividing the total number of deaths in persons who tested positive for SARS-CoV-2 (numerator) by the total number of SARS-CoV-2 cases (denominator) and this is expressed as a percentile in both (Fig. 6) and (Fig. 7) (Outbreak of COVID-19 2020). When societies prepare for potential COVID-19 diseases, regardless of underlying health problems, the risks of older people and those with weakened immune systems need to be remembered.

From this figure, we come to the conclusion that people with greater than or equal to 80 years of age had the highest fatality rate $(14.80 \%)$ than all the other age groups. Such type of people are at higher risk of severe COVID-19 infection or even death.

Since fatality and extent of illness have a connection with the age factor and comorbidities from (Fig. 6) and (Fig. 7), we must make sure that these high-risk groups of 


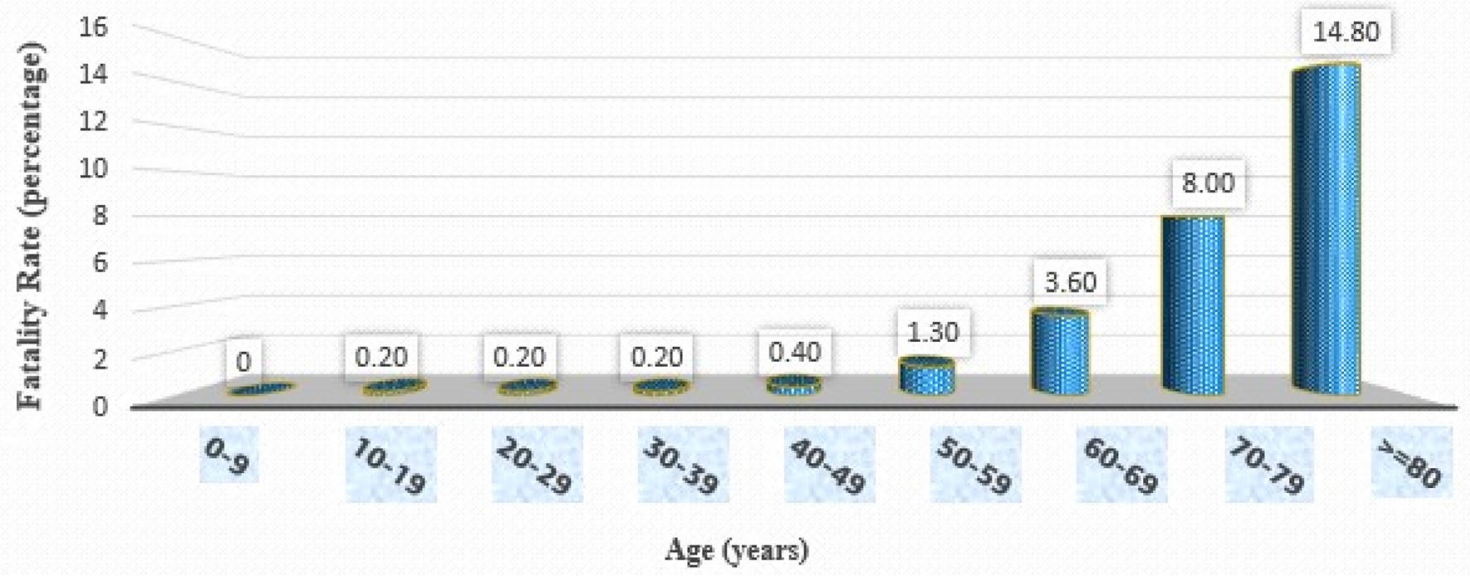

Fig. 6 Fatality rate by age-wise in Mainland China as of February 11th, 2020 (Outbreak of COVID-19 2020)

Fig. 7 Fatality rate with comorbid conditions in China as of February 11, 2020 (Outbreak of COVID-19 2020)

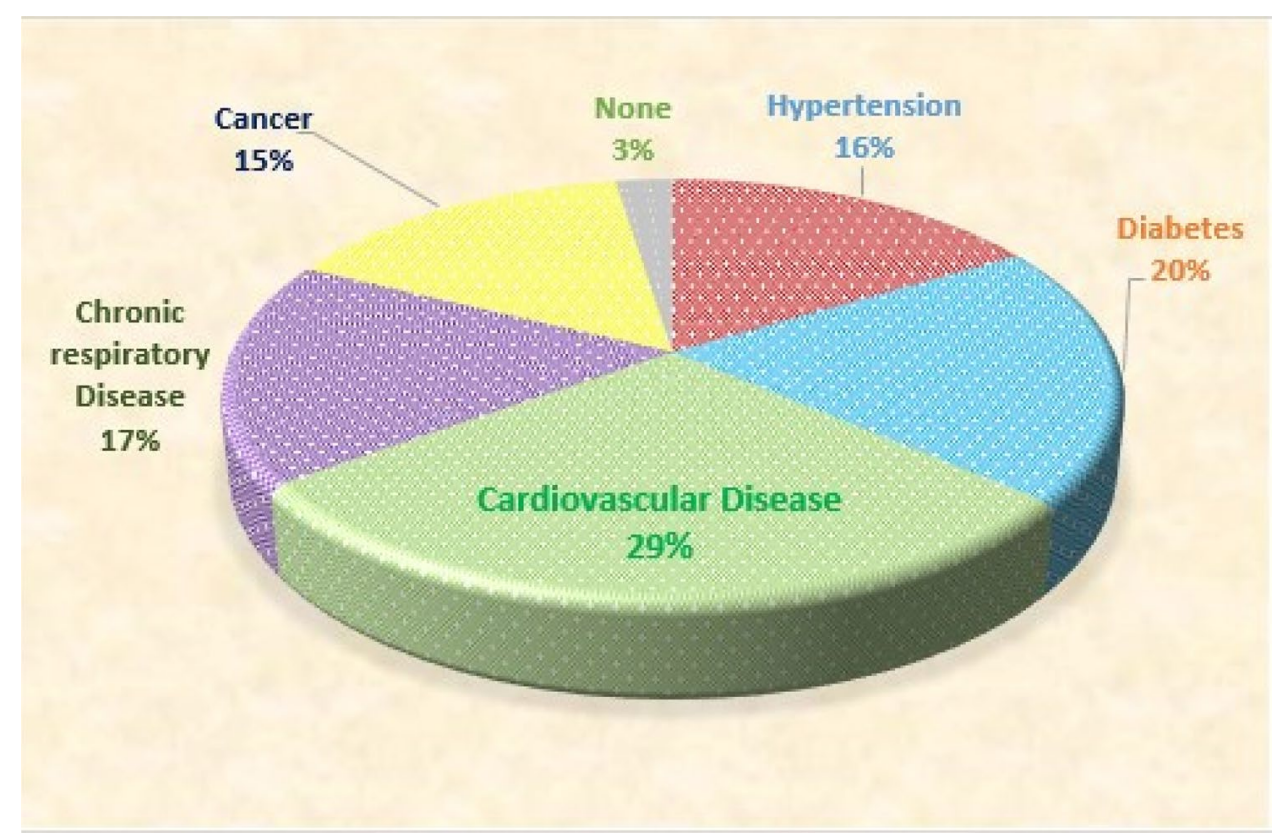

people have sufficient protection from infections and they should be subjected to early access to medical care when infected. These measures are important for improving their chances of survival (Outbreak of COVID-19 2020). Fatality rates were calculated by evaluating $n=44$, it was found that 672 confirmed cases in Mainland China in both (Fig. 6) and (Fig. 7) as of February 11th, 2020 (Outbreak of COVID-19 2020). Patients with no comorbid conditions had just $0.9 \%$ of mortality, whereas patients with comorbid conditions had much higher rates. So it is found that people, who are older, with higher Sequential Organ Failure Assessment (SOFA) score and elevated d-dimer at admission, were at high risk for death due to COVID-19 (Zhou et al. 2020). The Case fatality rate is considered as a great tool to express the fatality rate (Spychalski et al. 2020).

COVID-19 infected persons are identified by Reverse Transcriptase Polymerase Chain Reaction (RT-PCR) testing. This method is used to test the patients on the throat swabs (Onder et al. 2020). But it is reliable only in the first week of COVID-19 disease because after the first week it slowly starts to disappear on the throat and begins to multiply in the lungs. After the second week, the suction 
catheter is used to collect samples from the deep air breath of the affected person.

\section{Impacts on environment due to COVID-19}

Due to this pandemic COVID-19 spread, this transition has brought some unforeseen consequences in the environment. Compared to the last year, emission rates in many countries have fallen gradually. This shows how the environment is affected by regular day to day activities. This is considered as one of the best positive impacts of the quarantine during COVID-19. So the environmental impacts of COVID-19 are seen in various forms of pollution, the condition of birds and animals, and the disposal of harmful medicinal waste.

\section{State of air pollution during the quarantine period}

The coronavirus outbreak had led the world to shut down many cities, companies, and industries to ensure the safety of the workers. This had a great impact on the environmental changes in the quality of air, water bodies, etc.

Cleaner air has saved several lives in the last few months. There was a decline in the level of air pollution because of countries that are imposing strict quarantine and travel restrictions, the unintended decline in air quality from the virus outbreak is only temporary (British Broadcasting Council 2020). The long-term impact of the coronavirus pandemic on the world will depend on how countries respond to an economic crisis.

At the end of November 2020, Delhi, a city in India was found to have a bad or unhealthy quality of air. Data Intelligence Unit (DIU) reviewed the Central Pollution Control Board (CPCB) and the AQI (Air Quality Index) bulletin of Delhi. The 24-h average AQI (November 3rd, 4 PM to November 4th, 4 PM) showed that Jind in Haryana had analysed the most polluted air in 97 cities. The average AQI at Jind was 448 and AQI of Delhi was at 407 (Polluted cities 2019). During the period of Quarantine, the air quality of Delhi increased drastically and the AQI dropped to 150 from 400, this shows that the environment has a good impact due to the coronavirus outbreak (Improvement of air quality 2020).

\section{State of noise pollution during the quarantine period}

As the vehicle's movement has reduced during this quarantine, horn usage also decreased. Generally, unnecessary horn sounds will irritate people. This has reduced very much. Birds' sounds are heard more than any other sound during this lockdown. Birds are enjoying nature on their own by tweeting and chirping (Natural effect on this pandemic 2020).

Sound which is unnecessary and higher than the audible frequency level is considered as noise. The Entire city soundscapes are reduced, which may be pleasant to all the living creatures.

The Noise reduction helped the people who have high blood pressure and the disruption in sleep. Many people started to recall their peaceful childhood days because at that time vehicles were less (Natural effect on this pandemic 2020). Due to the shutdown of industries, the noise level has reduced to a great extent. If we follow the standards of transportation and reduce unnecessary noise, we can make this globe a pleasant and peaceful place to live in the near future too.

\section{State of water pollution during the quarantine period}

Water Pollution has also decreased much, this will lead to an improvement in the purity of freshwater sources. The famous water bodies such as Ganga and Yamuna in India have seen much improvement in freshness and its purity during the lockdown of the entire country (Impact on water bodies). These rivers are the two important freshwater sources, these should be protected. Freshness and purity should be maintained (Water quality improvement during the lockdown 2020). Due to the reduction in transportation of oil and goods via oceans, the chances of pollution of water like spilling of oils and waste into the ocean is reduced. (Effects of water pollution 2019).

\section{Biomedical waste disposal}

Many countries now have Biomedical Waste Management Regulations, the Central Pollution Control Board (CPCB) guidelines have been issued to ensure the scientific disposal of the waste generated while people research and treat COVID-19 patients. Biomedical waste is created during diagnosis, care, immunization of humans, animals or research, etc. (Biomedical waste regulations 2020).

Biomedical waste disposal regulations show how the waste produced during human diagnosis, treatment or immunization should be disposed of (Hegde et al. 2007). The waste consists of human skin, blood-contaminated products, body fat, and blood or body fluid pollution of the bedding. Sacks of blood, needles, syringe or all other sharp items infected (Hegde et al. 2007). For isolation wards in which COVID-19 patients are quarantined, it is noted that double-layered bags can be used as a precaution to capture waste in addition to regulations on biomedical waste to ensure adequate intensity and no leakage (Guidelines for Waste Disposal 2020). 


\section{Condition of birds and animals during quarantine}

Across a number of nations, when quarantine roll calls, people will spend more money on movies, social media, drama, and books. Nonetheless, nature does its thing and the people are experiencing an unforeseen quarantine result. In countries such as Japan, Italy, and Thailand, animals were observed roaming in the streets because of human absence. Due to quarantine both the birds and animals are feeling free to roam outside, the roads are completely empty there is no rush as normal days. It is considered as the Natural environmental change for both the birds and animals (Freedom of animals 2020).

Manufacturing products use energy and natural resources which creates pollution and waste production, some wastes like plastic bags and bottles in rivers, lakes which lead to negative consequences for endangered species and other animals. Now due to the COVID-19 pandemic situation birds and animals are feeling completely happy (Freedom of animals 2020).

\section{Primary treatments and traditional methods of curing}

Although there are no exact vaccines for treating COVID19 as of now, some methods of treatment or antiviral drugs have been effective in curing the patients. So to get rid of quarantine or to get discharged from hospital, the following conditions have to be met:

- Body temperature is supposed to be normal for longer than 3 days.

- It is important to strengthen the body and overcome respiratory symptoms.

- The radiological abnormalities or acute exudative lesions on chest computed tomography (CT) images must be enhanced to a greater version.

- Two consecutive results of RT-PCR (Reverse Transcription- Polymerase Chain Reaction) should be negative and these results must be at least $24 \mathrm{~h}$ apart (Lan et al. 2020; Pan et al. 2020).

\section{Use of antiviral drug}

No medicinal drugs have yet been proved safe and effective for the COVID-19 diagnosis. A variety of medicinal products have been proposed as possible research therapies, some of which are currently being tested in clinical trials during this pandemic situation which are cosponsored by WHO and other participating countries (World Health Organisation 2020b). (Table 1) provides common and potential antiviral drugs. In some countries, doctors are treating COVID-19 patients with drugs that were not approved for this disease. The use of licensed drugs for indications that are not approved by a national regulatory authority for medicinal products is marked "off label" use.

Table 1 represents some of the common and potent antiviral drugs used in clinical practice previously for some of the diseases.

Medicinal drugs prescribed by doctors for off label use may be subjected to national laws and regulations (World Health Organisation 2020b). Both healthcare staff should be aware of the laws and regulations regulating their practice and comply with them. In addition, the stipulation should be made on a case-by-case basis. It is necessary to avoid excessive stockpiling and creating shortages of approved medicines that are needed to treat diseases.

Based on the past experience of battling the SARS-CoV and MERS-CoV outbreaks, we have discussed certain prevention approaches against COVID-19.

\section{Chloroquine and hydroxychloroquine as a remedy}

Chloroquine is one of the drugs tested in China for COVID19. It was reported on February 4th, 2020, to inhibit SARSCOV-2 in vitro. National Health Commission of the People's Republic of China, included this drug in the COVID-19 treatment guidelines on February 15th, 2020. According to this guideline, the recommended dose for adults is about $500 \mathrm{mg}$ twice per day and it should not be continued for more than 10 days (Wong et al. 2020). Also, for adults, $5 \mathrm{~g}$ of chloroquine becomes lethal (Riou et al. 1988).

Chloroquine is a repurposed drug that is very effective in the treatment of COVID-19. Chloroquine is previously used as an antimalarial and autoimmune disease drug. This drug has now been identified as a possible antiviral drug of broad range (Wong et al. 2020). This drug acts as a novel class of autophagy inhibitor, which prevents further viral replication. Also, a combination of remdesivir and chloroquine was found to be effective in the treatment of COVID-19 (Guo et al. 2020).

Hydroxychloroquine which is an analogue of chloroquine has been found to have an anti-SARS-COV activity. It is also found that azithromycin added to hydroxychloroquine was found to be more efficient for eliminating the virus. The study revealed a higher proportion of people diagnosed with hydroxychloroquine and azithromycin relative to patients treated with hydroxychloroquine alone (Gautret et al. 2020).

\section{Kabasuraneer choornam}

The Kabasuraneer Choornam is a Siddha medicine that is used to cure many types of fever, flu, and respiratory illness (Ayurveda benefits 2020). It is specially used when there is 


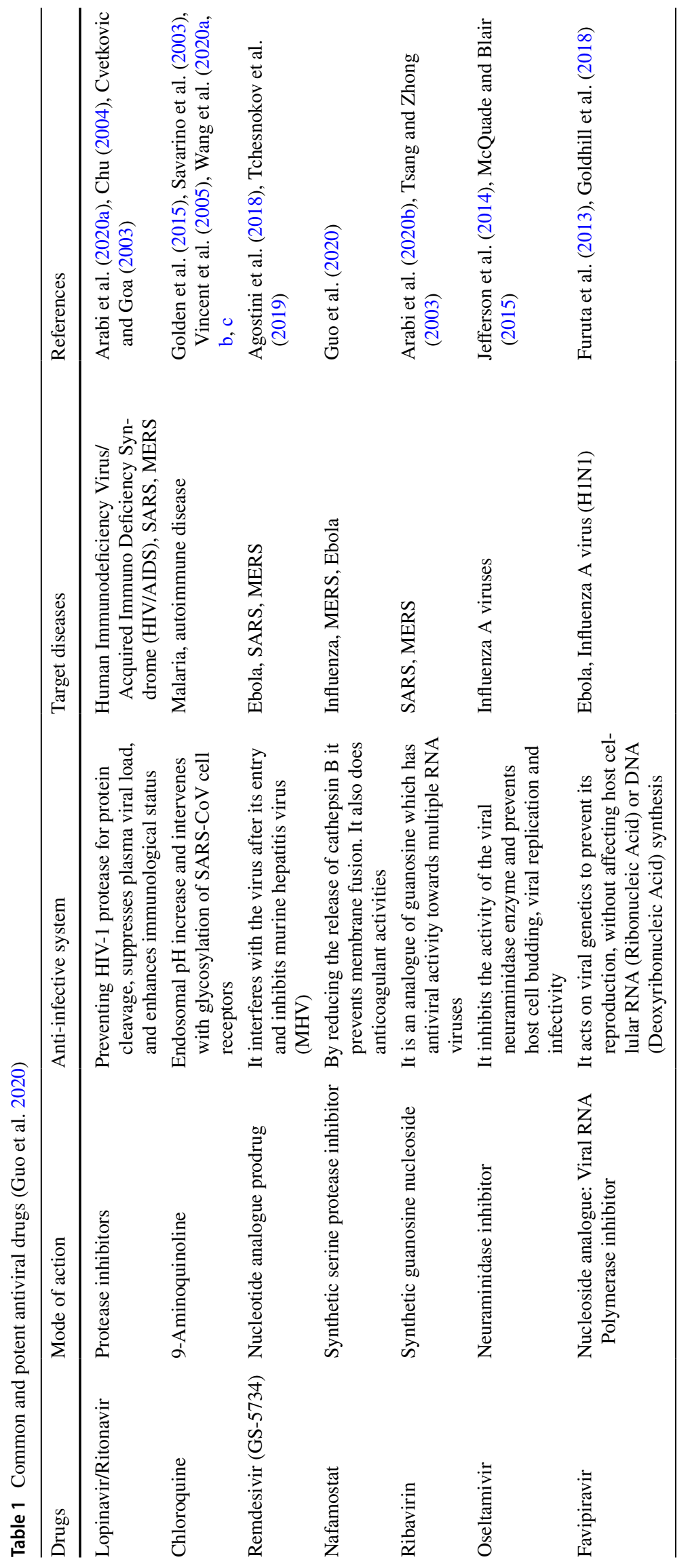


fever associated with cold, cough, and difficulty in breathing as it is used for treating various cases of flu (Ayurveda benefits 2020).

\section{Ingredients and preparation}

The Kabasuraneer Choornam contains nearly 15 types of medicinal herbs and they are chukku (dried ginger), thippili (piper longum), Cirukancori Ver (Tragiainvolucrata), seenthil (Tinospora Cordifolia), karpooravalli (Anisochilus carnosus), Lavangam (Syzygiumaromaticum), adathodai ver (root of Justiciabeddomei), korai kizhangu (Cyperus Rotundus), kostam (Costus Speciosus), akkara (Anacyclus pyrethrum), Vatta Tiruppur (Sida Acuta), MulliVer (Hygrophila Auriculata), nilavembu (Andrographis Paniculata), kanduparangi (Clerodendrum Serratum) and Kadukkaithol (Terminaliachebula) is found to be efficient in prevention and treatment of swine flu (Natural remedies to treat swine flu 2016).

The Kabasuraneer Choornam is prepared from the extract of Kabasura Kudineer Choornam, it is added to water and heated to about $50-60{ }^{\circ} \mathrm{C}$ till the water reduces to $1 / 8$ th of the volume. The Kabasuraneer Choornam is a Siddha medicine practised in India and mostly in southern India which is prescribed to increase the immunity against swine flu in 2015 (Saravanan et al. 2018).

Atleast eight of the herbs used in the preparation of the Kabasuraneer Choornam could neglect the replication of the virus and gives protection for the human body from
COVID-19, said by Sanjeev Biomedical Research Centre (Benifits of kabasura kudineer 2020). Phytocompounds bind to the coronavirus spike protein or surface protein and prevent it from binding to the human cell membrane receptors that serve as a barrier until it starts to replicate. If the Kabasuraneer Choornam is consumed before the virus is contracted, the phytocompounds will bind to the respiratory epithelial cells and strengthen the immune system and it also prevents the virus from linking with the human cells and replicating after the person gets affected by COVID-19.

The benefits of Kabasuraneer Choornam includes several phytochemical components that are responsible for antiinflammatory, antipyretic, analgesic, antiviral, antifungal, antioxidant, hepato-protective, anti-diabetic, anti-asthmatic, immunomodulatory, anti-diarrhoeal activity(Saravanan et al. 2018). It is said that the Kabasuraneer Choornam can be used against the COVID-19 virus by Siddha practitioners in India because it is a preventive remedy against various types of fever, flu and also increases the immunity of the human body (Ayurveda benefits 2020).

However, a Siddha practitioner, G. Sivaraman director of Arogya healthcare said that this drug cannot be used as treatment for COVID-19 and this drug is used to treat pneumonia like diseases in Siddha medicine (Remedy given by Siddha field 2020).

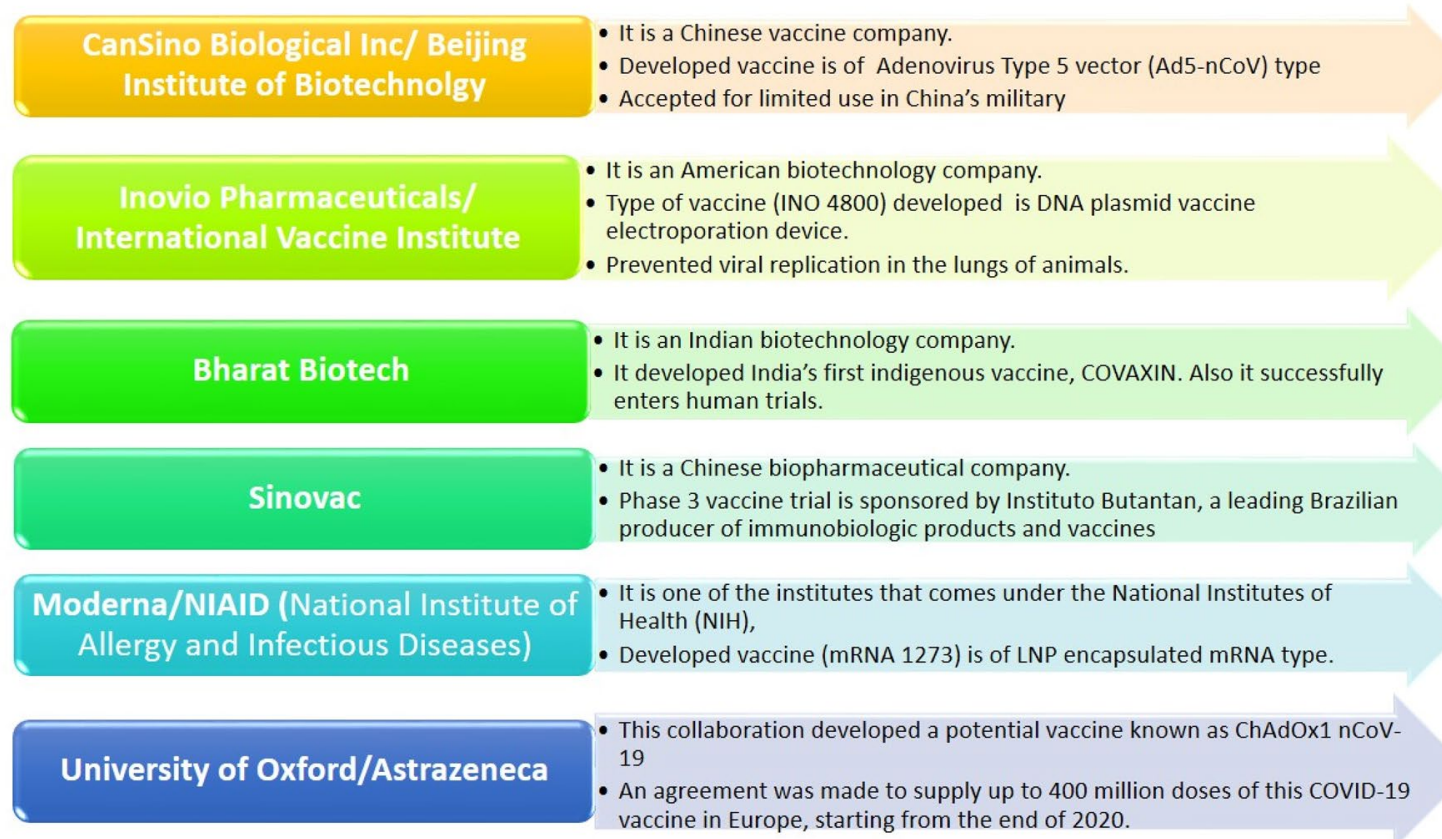

Fig. 8 Organisations involved in the development of vaccines as on 24th July, 2020 (World Health Organisation 2020d, CanSino vaccine 2020; Inovio vaccine 2020; Sinovac vaccine 2020; Bharat Biotech vaccine 2020; AstraZeneca vaccine 2020) 


\section{Vaccine}

At present, there are three COVID-19 immunizers coming up; The most reassuring of them is the COVID-19 immune response made by the University of Oxford and pharmaceutical association AstraZeneca. Another immune response made by Chinese pharmaceutical firm Sinovac Biotech has entered the last stage of testing. Moderna Inc's COVID-19 immune response antibody is in the final stage works (Research updates on vaccine 2020).

AstraZeneca has joined Serum Institute of India (SII), the world's biggest immunization makers by the number of portions created and sold, to deliver the possible antibody in India. The human trials of Oxford COVID-19 immunization have just begun in Brazil. If any of these vaccines have proved its success, then we can slowly reduce this pandemic to a normal situation (Research updates on the vaccine 2020). Some of the developers of vaccines that are in the clinical evaluation stage as on 24th July, 2020 are shown in (Fig. 8).

\section{Precautions to be taken}

In this section, the preventive measures for both people and medical staff given by central governments from the World Health Organisation will be elucidated. Preventive measures should be taken otherwise, the risk of disease transmission will be more. According to the English proverb "Prevention is better than cure", prevention is the best thing that we can follow, until the proper medicine or vaccination is found.

The preventive measures that can be adopted to prevent human from getting COVID-19 infection, they are as follows:

- Hygiene should be maintained.

- 70\% alcohol-based hand rub, liquid soap can be used by people.

- Avoid touching each other and maintain social distancing for $1 \mathrm{~m}$.

- Stay home, seek medical attention if you have the symptoms of cold, fever, and problems in respiration. Follow the guidelines of the local health authority.

- Personal protective equipment [PPE] such as sterile gloves, face shields, aprons, sterile gloves, gowns, protective goggles, scrubs, masks (N95 or FFP2) must be used by medical staff. (Adams and Walls 2020).

- Medical staff and paramedical workers should self-quarantine themselves for alternate weeks.

- Doctors should sterilize themselves before and after attending the patients.
- Reducing the contacts with the family members during the crisis.

- Screening people and risk assessment should be well planned and managed.

- Environmental cleaning and spraying disinfectant in local areas is a must.

- Spreading awareness among people through online videos can be done.

- Overcrowding in the areas of essential places such as markets should be strictly avoided (World Health Organisation, 2020c).

\section{Technologies-A boon to mankind}

Since the COVID-19 pandemic has forced to close educational institutions and industries, we have to depend on Cloud Based Technologies to connect students with educational institutions and also artificial intelligence-enabled robots can prove to be helpful for many industries to work during these pandemic.

Without these advancements in technologies, this lockdown would be hard for individuals to cope up. Individuals will feel exhausted at their home. Presently, they are engaged with their movies on online streaming platforms. If there was isolation during the olden days, people would

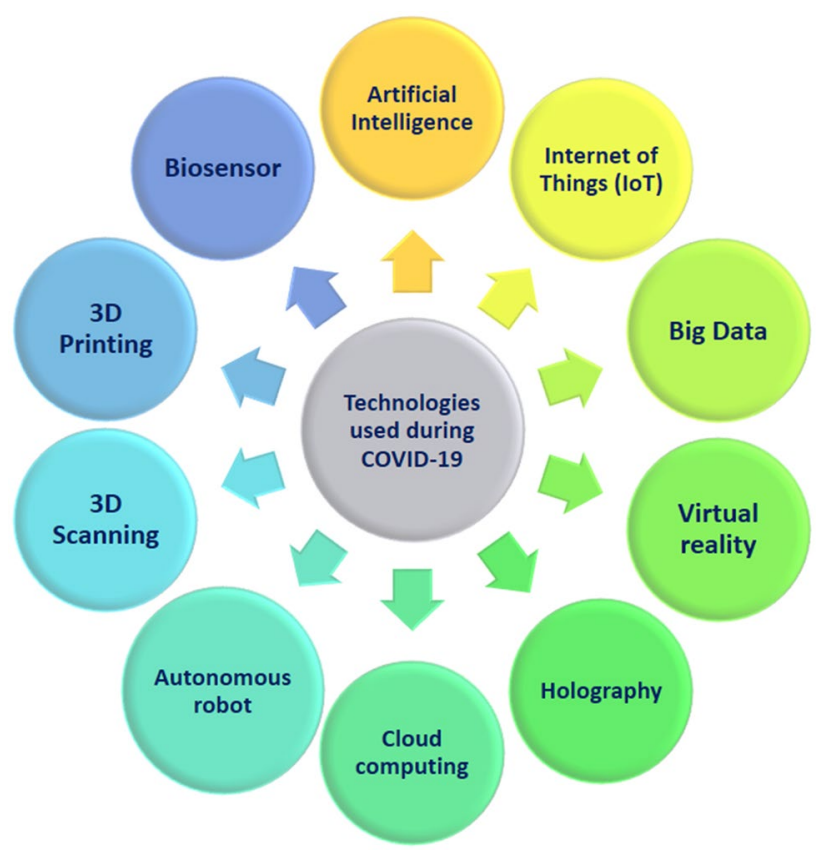

Fig. 9 Technologies used during COVID-19 (Javaid et al. 2020). These technologies helped mankind to invent new products like face masks (developed by 3D Printing), IR Thermometer (Bio Sensors) to provide safety for human beings and for the front line workers

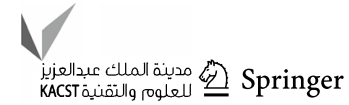


feel stressed without cell phones and media transmission. But nowadays, individuals are getting occupied with these innovations.

Technologies also played a vital role in data Collection (Artificial Intelligence and Big Data), Online Classes (Virtual Reality) etc. Some of the other technologies were also used to tackle this pandemic condition as shown in (Fig. 9).

\section{Artificial intelligence}

Artificial Intelligence has a feasible contribution in fighting against COVID-19 as well as existing constraints. In terms of life and economic destruction, the risk of a pandemic is terrible. Improving Artificial Intelligence and data analytics technologies have evolved continuously over the last decades. Because of the lack of evidence, Artificial Intelligence has not been impactful against COVID-19 yet. Overcoming these constraints requires careful consideration of data privacy and public health issues as well as the interaction between human Artificial Intelligence. It will be necessary to gather diagnostic data from infectious people to save lives and reduce the economic havoc due to containment (McCall 2020).

The goal of Artificial Intelligence is to deploy decision support using predictive analysis. Artificial Intelligence can help people by predicting the case of COVID-19 which helps them to identify persons affected and take actions in a faster manner.

Patients with 2019 confirmed n-CoV infection suffer from respiratory illness, fever, and cough. Incubation time ranges from 2 days to 2 weeks (Carlos et al. 2020). Supervised training is a practice and learning process. Accordingly, the computers are equipped with sample data and then used for predicting new sampling of the results. The vast collection of health data from a wide range of outlets types include genome screening, Electronic Health Records (EHR), and wearables contributed to biomedical big data (Elavarasan and Pugazhendhi 2020).

Artificial Intelligence was praised for its possible contribution to the development of new medicines. Artificial Intelligence helps in finding new drugs and a COVID-19 vaccine. Artificial Intelligence creates an aid clinical preliminaries which are ought to perceive the ailment in patients, distinguish the quality targets and foresee the impact of the particle structured just as the on-and off-target impacts (Mak and Pichika 2019) Data is used to run Artificial Intelligence models; It helps to handle the pandemic more efficiently.

\section{Alerts and early warnings}

Early warning is a much better way to cure the pandemic. A basic urine test is expected to assist clinical experts in recognizing future decompensation of COVID-19 disease (Early warnings 2020). The case of the Artificial Intelligence model based in Canada, Blue Dot, has already become legendary. This shows that Blue Dot, a fairly low-cost Artificial Intelligence platform. It can predict infectious disease outbreaks in humans (Predetermining Artificial Intelligence 2020). Blue Dot predicted the outbreak of the infection by the end of 2019, according to accounts, where it identified the top 20 destination cities where Wuhan passengers will arrive. This warned that those cities may be at the forefront of the disease's global spread.

\section{Surveying and predicting}

Patients with suspected 2019-nCoV were admitted and quarantined, and samples of the throat swab were obtained and the same data is sent to the 2019-nCoV Chinese Centre for Disease Control and Prevention using a quantitative polymerase chain reaction test and the surveyed data was very much useful for the Analysis of the COVID-19 disease (Chang et al. 2020). Artificial Intelligence can be used to monitor and predict how COVID-19 will spread over the period of time.

For instance, a dynamic neural network was built to predict its spread following a previous pandemic, Zika-virus of 2015. Algorithms were formulated to predict seasonal flu are now being retrained on new COVID-19 data at Carnegie Mellon University.

\section{Analysis and forecast}

The atypical case of pneumonia, caused by a novel coronavirus (2019-nCoV), was first documented and confirmed on 31st December 2019 in Wuhan, China (Zhao et al. 2020). Fast and accurate COVID-19 diagnosis will save lives, limit disease spread, and generate data on which to train models of Artificial Intelligence. Artificial intelligence may provide valuable feedback in this regard, in particular with a diagnosis based on images (Predetermining Artificial Intelligence 2020).

According to a recent study by researchers working with UN Global Pulse of Artificial Intelligence applications against COVID-19, studies have shown that Artificial Intelligence can be as reliable as human beings, can save the time of radiologists and diagnose faster and cheaper than regular COVID-19 tests (Predetermining Artificial Intelligence 2020).

\section{Deep learning and machine learning in the field of medicine}

The field of Biology and Modern Medicine is making more tremendous upgraded technology which is becoming DataIntensive, by using these data and the field of deep learning 
technology is more helpful in treating the patients (Ching et al. 2018). Deep Learning is useful when a problem arises with a patient of a particular disease, the data which is input to the computer represents the disease in the patient, the computer analyses many logical symptoms in the patient and the treatment is given according to the results of the computer (Hinton 2018).

Machine learning has proved effective in many analytical areas of risk. Machine learning probably matters in three major areas, with clear medical risk (Machine Learning in Healthcare 2020).

- Danger of infection What is the risk of having COVID-19 for a specific person or group?

- Risk of severity What is the risk of extreme COVID-19 symptoms or complications requiring hospitalization or intensive care of a specific patient or group?

- Result probability What is the probability of the ineffectiveness of a medication for a specific person or group?

Theoretically, learning by computer can aid in detecting all three risks. Although it is still too early to get some COVID-19-specific machine learning research completed and written, early findings are very positive. We can also understand how machine learning can be used in related fields and how it can assist with COVID-19 risk prediction (Machine Learning in Healthcare 2020).

Early statistics indicate that important risk factors that decide the probability of a person contracting COVID-19 include: sex, pre-existing illnesses, general grooming practices, social behaviour, amount of interaction between individuals, duration of interactions, place, and climate, socioeconomic status(Machine Learning in Healthcare 2020) (see Fig. 10).

Machine learning has the potential to support clinicians' work processing and management of large amounts of medical data contained in electronic health records and used in clinical applications which includes recognizing high-risk patients in need of ICU, the identification of early signs of lung cancer, determination of patient's respiratory status from X-rays in the chest, such deep learning approaches employ neural networks to predict the input-output data relationship. Another potential feature of ML is its ability to reduce the cost of operation and product, automate, and enhance customer support (Elavarasan and Pugazhendhi 2020).

Deep Learning works more similar to machine learning where it can be separated into two types as "Supervised Applications- where the predicted goal is achieved accurately and Unsupervised Applications-where the goal is to summarize the data outcomes and identify the patterns of the outcome data" (Hinton 2018).

Deep neural network (Fig. 10) is learned and trained over a large set of data and they work on the multiple layers for the specified results and they are more accurate because they are learning from the previous outcomes of the data obtained (HealthIT Analytics 2018; Hinton 2018). Machine learning and the rapid advancement of deep learning based technologies have demonstrated their ability to transform these big data in biomedical applications to a functional form. In general, AI and ML are introduced at the healthcare has increased patient safety, and successful treatment, and healthcare costs also has got reduced(Elavarasan and Pugazhendhi 2020).

When data on COVID-19 is collected and analysed by a deep learning network it would save as many lives as possible and the computers would suggest the doctors for the treatment. Deep learning helps in the classification of each and every task by the use of multiple layer strategy in the patients with the risk abnormalities found earlier with the same symptoms and by means of medical imaging (Table 2) (Switching Healthcare 2018). Deep Learning is a key technology where predictive healthcare systems can be developed, which can have access to a billions of data of the patients for the next generation (Hinton 2018).

Table 2 provides a list of deep learning data and its uses in diverse medical fields and where data can be gathered and therapies provided to patients.
Fig. 10 Deep learning network to work on COVID-19 (Miotto et al. 2018; Machine Learning in Healthcare 2020)

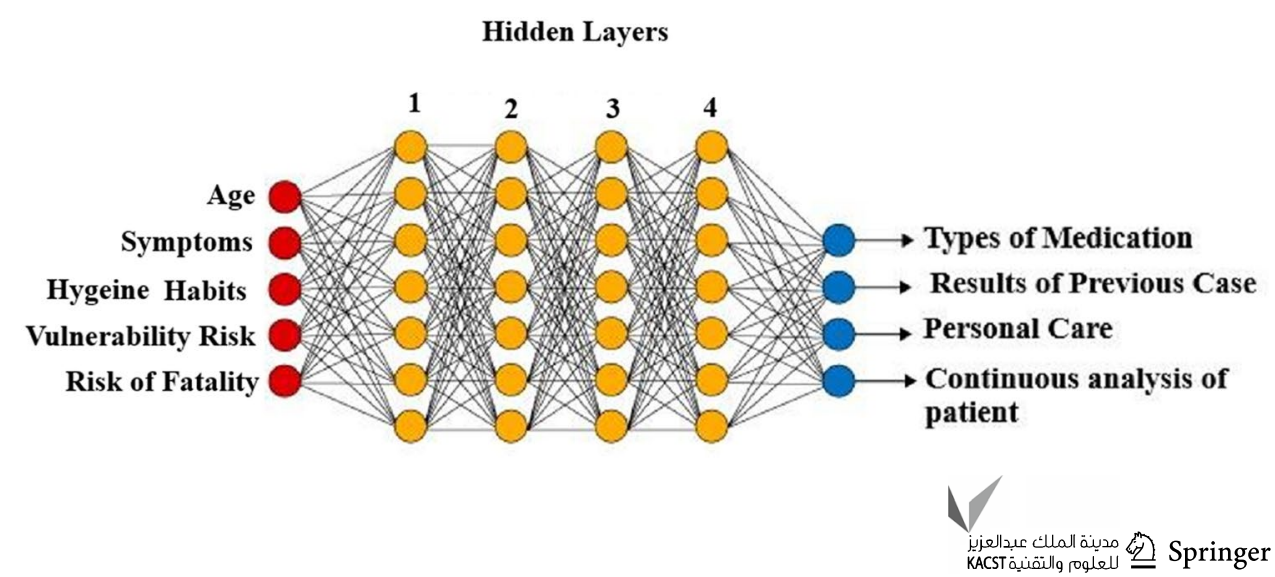


Table 2 Applications of deep learning (Hinton 2018)

\begin{tabular}{|c|c|c|}
\hline Types of data & Application & References \\
\hline \multirow[t]{5}{*}{ Electronic health records } & $\begin{array}{l}\text { It helps in indicating different population subtypes and to differentiate symptoms of } \\
\text { gout and acute leukemia from uric acid }\end{array}$ & Lasko et al. (2013) \\
\hline & Assigns the diagnosis process for the patients by previous clinical status & Liang et al. (2014) \\
\hline & To know about heart failure and chronic pulmonary illness in advance & Cheng et al. (2016) \\
\hline & Advanced treatments over the onset of diseases by predicting from lab results & Razavian et al. (2016) \\
\hline & End-to-end method for forecasting after discharge unplanned readmission & Nguyen et al. (2016) \\
\hline \multirow[t]{4}{*}{ Clinical imaging } & $\begin{array}{l}\text { Advanced imaging using Magnetic Resonance Imaging (MRI) Scan to detect Alzhei- } \\
\text { mer's disease }\end{array}$ & Brosch and Tam (2013) \\
\hline & Segmentation of knee cartilage using MRIs to know about damage of tissues & Prasoon et al. (2013) \\
\hline & Alzheimer's diagnosis from the brain's MRI can be diagnosed early & Liu et al. (2014) \\
\hline & Skin cancer classification before the lab tests & Esteva et al. (2017) \\
\hline \multirow[t]{5}{*}{ Genomics } & Cancer recognition by profiles in gene expression & Fakoor et al. (2013) \\
\hline & Protein backbone analysis out of protein sequences & Lyons et al. (2014) \\
\hline & Estimation of Energy Expenditure (EE) using wearable sensors & Zhu et al. (2015) \\
\hline & Identify photo plethysmography signs for tracking wellbeing & Jindal et al. (2016) \\
\hline & $\begin{array}{l}\text { In single-cell sequencing, can perform tests of bisulfite ion }\left(\mathrm{HSO}_{3}{ }^{-}\right) \text {estimate methyla- } \\
\text { tion levels }\end{array}$ & Angermueller et al. (2017) \\
\hline
\end{tabular}

Table 3 Some important applications used in India to control the pandemic

\begin{tabular}{|c|c|c|c|c|}
\hline Apps & State/Central Government & Functionality & Description & References \\
\hline Aarogya Setu & $\begin{array}{l}\text { Government of India/ } \\
\text { National Informatics Centre }\end{array}$ & $\begin{array}{l}\text { Contact Tracing, Self- } \\
\text { assessment, Syndrome } \\
\text { mapping }\end{array}$ & $\begin{array}{l}\text { Alerts us if an affected per- } \\
\text { son comes in proximity }\end{array}$ & $\begin{array}{l}\text { Livemint (2020), Gizbot } \\
\text { (2020) }\end{array}$ \\
\hline COVID-19 Feedback & $\begin{array}{l}\text { Indian Ministry of Elec- } \\
\text { tronics and Information } \\
\text { Technology }\end{array}$ & Survey tool & $\begin{array}{l}\text { Used to detect affected } \\
\text { areas and enhance the test- } \\
\text { ing facilities }\end{array}$ & Geospatial World (2020) \\
\hline Sahyog & $\begin{array}{l}\text { India's national mapping } \\
\text { agency, Survey of India }\end{array}$ & $\begin{array}{l}\text { Contact Tracing, Deliver- } \\
\text { ies of essential items to } \\
\text { affected individuals }\end{array}$ & $\begin{array}{l}\text { Collects data at the state } \\
\text { level and analyse it }\end{array}$ & Geospatial World 2020) \\
\hline $\begin{array}{l}\text { COVID-19 Quarantine } \\
\text { Monitor }\end{array}$ & Government of Tamil Nadu & $\begin{array}{l}\text { Contact Tracing, Geofenc- } \\
\text { ing }\end{array}$ & $\begin{array}{l}\text { Ensures that people under } \\
\text { the quarantine does not } \\
\text { violate the guidelines }\end{array}$ & Geospatial World 2020) \\
\hline $\begin{array}{l}\text { Corona Virus Alert App } \\
\text { (COVA) }\end{array}$ & Government of Punjab & $\begin{array}{l}\text { Contact Tracing, Self- } \\
\text { assessment }\end{array}$ & $\begin{array}{l}\text { Generate curfew passes, } \\
\text { users can connect to the } \\
\text { doctors }\end{array}$ & Gizbot (2020) \\
\hline Test Yourself Goa & $\begin{array}{l}\text { Government of Goa/Inno- } \\
\text { vaccer }\end{array}$ & Self-diagnostic & $\begin{array}{l}\text { This notifies users if they } \\
\text { have symptoms, depending } \\
\text { on the responses. It also } \\
\text { offers guidance on how to } \\
\text { quarantine oneself }\end{array}$ & Geospatial World (2020) \\
\hline COVID E-Bazaar & Government of Rajasthan & $\begin{array}{l}\text { Deliveries of essentials } \\
\text { items to affected individuals }\end{array}$ & $\begin{array}{l}\text { It is used to meet the } \\
\text { requirement of people dur- } \\
\text { ing this pandemic }\end{array}$ & Gizbot (2020) \\
\hline
\end{tabular}

\section{Apps used in controlling pandemic}

There are several applications used for helping the government. Some of the important apps used in India to control the pandemic condition is shown in (Table 3 ) and some of the top applications used in the world to tackle the COVID19 is shown in (Fig. 11). These applications give clear monitoring status, feedback and also give guidelines to be followed by the people. It gives several updates about contact tracing which will be very much useful to the people. These applications utilise the telephone's Bluetooth and GPS capacities. It will track the affected persons by utilizing Bluetooth. 
Fig. 11 Top Applications used in the world to control the pandemic (Covid Watch 2020), (Central and Eastern Europe Legalblog 2020), (Immuni 2020), (COVID-19 SmartPhone Applications 2020)

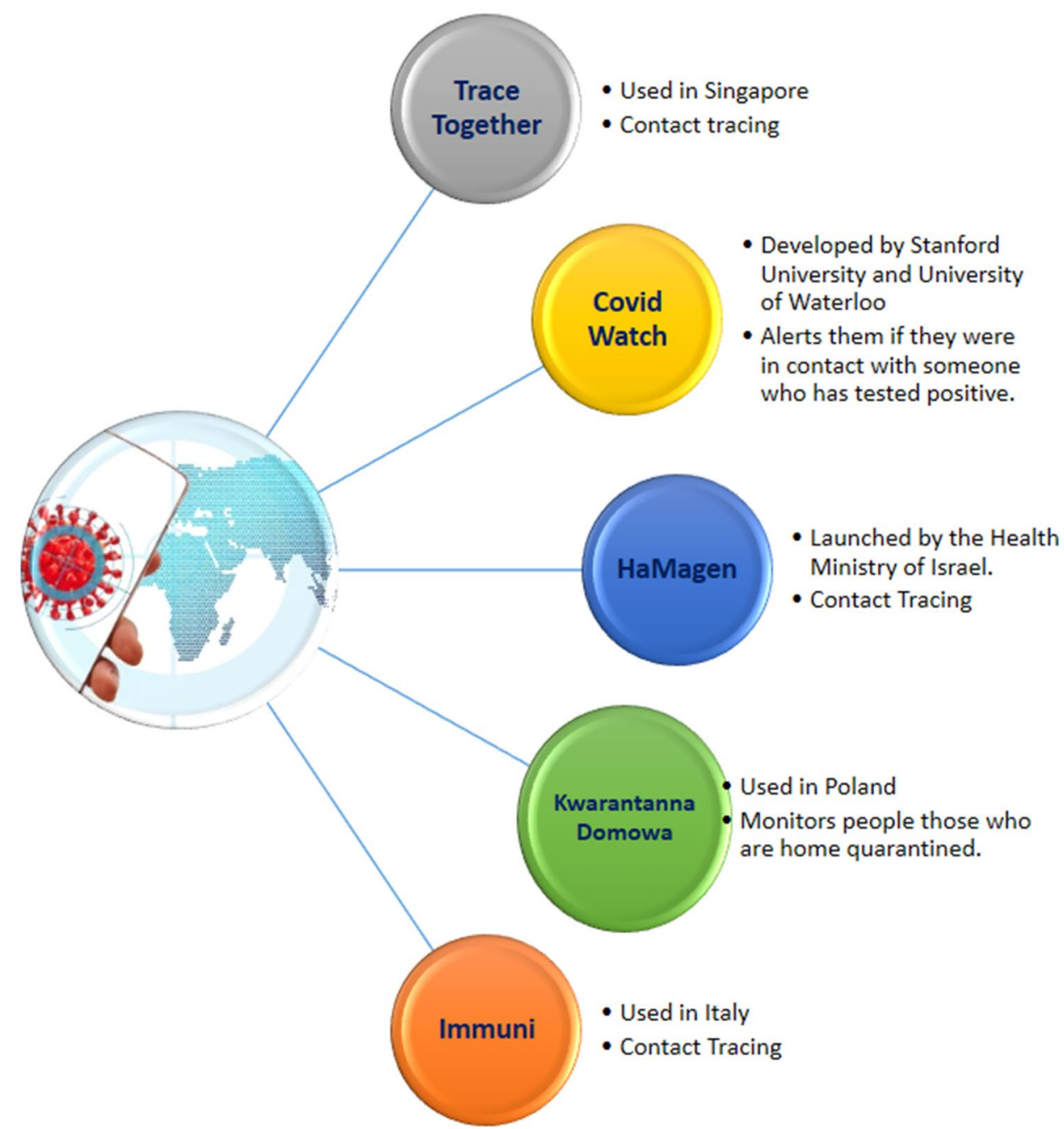

Table 3 provides the information about the list of applications and their functionality developed by the Indian government to handle the pandemic condition.

\section{Benefits of loT platform}

The Internet of Things (IoT) could be a well-defined platform of interconnected computing strategies, computerized, and mechanical gadgets having the capability for transmission of information over the defined network without having any human inclusion at any level (Singh et al. 2020).

In addition, no research in the current literature attempts to analyze the position of emerging technologies like IoT. It is a well-developed scheme of interconnected computing techniques, physical and mechanical devices with data communication capabilities over the specified one. Network without any degree of human involvement (Singh et al. 2020).

IoT is a way beyond concept which develops a general architectural history, which allows for integration and record of an individual. These data will be updated on the mobile application if any person is tested with positive COVID-19. This will be done on the basis of an appraisal review of every individual. In such infected cases, the records will be transferred to the servers (Tracking Apps for COVID-19 2020). 
effective exchange of data between needy persons and service providers. In the latest problematic pandemic scenario, the number of globally infected patients are growing day by day, and there are a large number of the sufficient and well-organized facilities provided with the methodology of IoT. In addition IoT already is also used for the purposes being demanded in various domains in healthcare (Mohammed et al. 2020) (see Fig. 12).

\section{Plasma donations}

Plasma is the fluid piece of blood that is gathered from patients who have recouped from the COVID-19. This disease is brought about by the infection named SARS-CoV-2. COVID-19 patients create antibodies in the blood against the infection. Antibodies are proteins that may help to fight against the contamination (Food and Drug Administration 2020). Individuals who have completely recuperated from COVID-19 in the last 14 days are urged to consider giving plasma, which may help the lives of different patients. COVID-19 based healing plasma should possibly be gathered from recuperated people in the event that they are qualified to give blood.

People should have an earlier analysis of COVID-19 recorded by a research centre test and meet other contributor models. People must have a total goal of manifestations for the past 14 days before plasma donation. A negative lab test for dynamic COVID-19 ailment is not required for plasma donation (Food and Drug Administration 2020).

\section{Role of technologies to minimize the effect of pandemic}

There are many technologies that are used to reduce the effect of this pandemic, some of them are as follows, Big data investigation helps in studying the infected individuals very effectively. These frameworks can control the development of the pandemic and also aids in observing individuals who are isolated. It also keeps an eye on individuals to check whether they are infected or they have been in contact with a contaminated individual. (Management during Pandemic 2020).

Self-driving vehicles, automated drones, and robots would be able to avoid human interaction. Automated vehicles can be used to move impaired people to and from the medical service offices, without bargaining individual's lives. Robots can be utilized in the circulation of food, warming, medical clinic sanitization, and road watching. These technologies help people who are facing many difficulties during these lockdown period (Management during Pandemic 2020).

\section{Online education platforms}

Currently, digital learning is gaining its popularity and also it the trend which is heading forward in modern educational activities, models, and processes. This will be the big moment for the online learning and educational approaches that will be re-planned much like the businesses that are going to operate remotely (work from home) because of the COVID-19. The present scenario has pushed scholars and educational institutions towards online learning plans and technology (Online Education 2020).

E-learning training is very useful in this pandemic situation because it is instantly accessible and it also offers flexible scheduling for the training (Computer Aided Elearning Team 2020). Since virtual classrooms are important for student-faculty interaction, video conferencing platforms like Google meeting and Webex are getting used extensively by many educational institutions. Also, software like Proctorio, a Google Chrome extension that monitors whether students take their online exams regularly, which has helped the educational institutions to keep track of the students, who take up their online exams regularly. So, the learning has become digitized and this will help us to get rid of the use of paper and costly textbooks (Online Education 2020).

These online classes offer a highly effective learning atmosphere for students so that they can learn from their respective locations (Computer-Aided E-learning Team 2020). Such initiatives and steps taken by the educational institutions are important because extended school closure and home isolation during a pandemic could have negative effects on the physical and mental health of children (Wang et al. 2020a, b, c).

With more than 560 million web clients, India is the second biggest online market among all countries, positioned distinctly behind China. It was evaluated that by 2023 , there would be more than 650 million web clients in the nation. Regardless of the huge base of web clients, the web entrance rate in the nation remained at around 50\% in 2020. This statistics imply that around half of the 1.37 billion Indians started using internet accessibility that year. There has been a steady increase in web accessibility but it is contrasted with only the past 5 years, when the web entrance rate was around 27\% (Statistical Usage 2020). Though India is the second biggest online market among all countries, some children in rural areas are lagging behind, without the internet facility. This would rule out a large proportion of children from rural areas in Internet usage (Online Education 2020).

Since the confirmed cases and deaths due to COVID-19 are rapidly increasing day by day, both medical staff and the public have been undergoing psychological problems, like 
depression, stress, and anxiety. Also, the transmission of viruses takes place at a faster rate between people.

This obstructs face-to-face psychological interventions. Therefore, internet services and telecommunication helped health care professionals to provide mental health support online during the COVID-19 outbreak (Liu et al. 2020a, b).

\section{Drone technologies}

Since epidemic contagious diseases mostly interrupt the movement of people, transportation systems, and mobility of commodity, the use of drones in this situation will relieve humanitarian aid. The use of drones and quadcopters will generally help to do certain things like (i) Evaluate and analyse the infected area by aerial monitoring (ii) Epidemic cargo and logistic delivery (Estrada 2020) (iii) Aerial spray and disinfection (Drone Technologies 2020).

Unmanned aerial vehicles are used to monitor the people, who were unnecessarily roaming in the streets. Those people can be warned and sent back through this facility. Disease transmission can be controlled to a greater extent and it is cost-efficient. By travelling, a high quantity of fuel will be wasted and it is not practically possible to monitor all the areas. Aerial monitoring systems will be helpful for the reduction of COVID-19 transmission (Benefits of drones 2020).

Drones were used in China and Dubai to spray disinfectant chemicals in public places and on vehicles for disease prevention so that the transmission mechanism gets reduced. Justin Gong, co-founder of an agricultural drone company said that spraying disinfecting chemicals using drones has been more effective in comparison with hand spray (Drone Technologies 2020). The use of drones is a great boon for the workers and it reduces the risk of being infected by the pandemic in the infected areas.

In India, these drones are effectively used to control the spread of the disease. If the people are seen outside doing mischievous activities they would be spotted and punished or warned. Drones are very much useful to monitor a highly populated country like India. Otherwise, the disease transmission rate would be even higher.

\section{Conclusion}

The COVID-19 outbreak has shown the pathway of hygiene for people all over the world. We must learn from mother nature to give equal rights to all living beings in the world and we must uphold it as a superior sense. It is our duty to protect nature for ourselves and for future generations. The pandemic has demonstrated the world's best new technologies that can hold children up to date with lectures, courses, and more online learning and educational exams that have contributed to a landscape of modern interfacing within months. The advanced AI and Machine Learning systems tend to operate the industries while the whole planet is being shut down due to the epidemic and the industrial goods are already being processed by these systems.

The lockdown of cities has reinforced the relationship within a family by obtaining more freedom to communicate with each other, and it has been found that the use of traditional medicines has a great influence on the society. Also during the quarantine period, people have learnt a great lesson from the epidemic of a novel coronavirus, the sophisticated technology supports the community with drones disinfecting the cities, interfacing robots, and gathering data from the infected communities without transmitting the virus to the physicians. The risk of being affected is high to the workers in the frontline, also people who travelled from other countries can be quarantined for the safety of their family, and the surroundings. The people who ever recognize the symptoms can admit themselves to test them for the disease, rather than being detected at the final stage of the illness. The human race had faced many outbreaks of many contagious diseases and had overcome those problems by increasing the immune power which can be a solution for this outbreak.

Acknowledegements The authors thank Dr.S.Sivaramakrishnan MS ORTHO and Dr. M. Jayalalitha MBBS, Shanthi Ortho Care Hospital, Tiruchirappalli, Tamil Nadu, India. They have helped us by suggesting some practical issues that are faced by the Corona Virus affected patients and the doctors working in the hospital during the COVID-19 period. The inputs received has helped the authors in framing certain important sections of the paper.

\section{Compliance with ethical standards}

Conflict of interest The authors declare that they have no conflict of interest.

\section{References}

Adams JG, Walls RM (2020) Supporting the health care work force during the COVID-19 Global Epidemic. JAMA 323(15):14391440. https://doi.org/10.1001/jama.2020.3972

Agostini ML, Andres EL, Sims AC, Graham RL, Sheahan TP, Lu X, Smith EC, Case JB, Feng JY, Jordan R, Ray AS, Cihlar T, Siegel D, Mackman RL, Clarke MO, Baric RS, Denison MR (2018) Coronavirus susceptibility to the antiviral remdesivir (GS-5734) is mediated by the viral polymerase and the proof reading exoribonuclease. MBio. 9(2):e00221-e318. https://doi.org/10.1128/ mbio.00221-18

Angermueller C, Lee HJ, Reik W, Stegle O (2017) DeepCpG: accurate prediction of single-cell DNA methylation states using deep learning. Genome Biol 18(1):67. https://doi.org/10.1186/s1305 9-017-1189-Z

Arabi YM, Asiri AY, Assiri AM, et al (2020a) Treatment of Middle East respiratory syndrome with a combination of lopinavir/

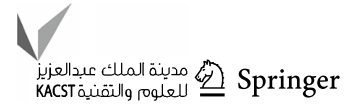


ritonavir and interferon- $\beta 1 \mathrm{~b}$ (MIRACLE trial): statistical analysis plan for a recursive two-stage group sequential randomized controlled trial. Trials. https://doi.org/10.1186/s13063-019-3846-x

Arabi YM, Shalhoub S, Mandourah Y, Al-Hameed F, Al-Omari A, Qasim EA, Jose J, Alraddadi B, Almotairi A, Khatib KA, Abdulmomen A, Qushmaq I, Sindi AA, Mady A, Solaiman O, AlRaddadi R, Maghrabi K, Ragab A, Mekhlafi GAA, Balkhy HH, Harthy AA, Kharaba A, Gramish JA, AlAithan AM, Al-Dawood A, Merson L, Hayden FG, Fowler R (2020b) Ribavirin and interferon therapy for critically ill patients with middle east respiratory syndrome: a multicenter observational stud. Clin Infect Dis 70(9): 1837-1844. https://doi.org/10.1093/cid/ciz544

AstraZeneca vaccine (2020) AstraZeneca and Oxford University announce landmark agreement for COVID-19 vaccine. https:// www.astrazeneca.com/media-centre/press-releases/2020/astra zeneca-and-oxford-university-announce-landmark-agreementforcovid-19-vaccine.html. Accessed 26 July 2020

Ayurveda benefits (2020) Kabasuraneer Choornam uses, dose, ingredients, side effects. https://www.ayurmedinfo.com/2019/11/27/ kabasura-kudineer-chooranam/. Accessed 7 Apr 2020

Benefits of kabasura kudineer (2020) Ingredients in Kabasuraneer Choornam can fight Covid-19. https://timesofindia.indiatimes .com/city/chennai/ingredients-in-kabasura-kudineercanfigh t-covid-say-researchers/articleshow/75335027.cms. Accessed 26 April 2020

Bernheim A, Mei X, Huang M, Yang Y, Fayad ZA, Zhang N, Diao K, Lin B, Zhu X, Li K, Li S, Shan H, Jacobi A, Chung M (2020) Chest CT findings in coronavirus disease-19 (COVID-19): relationship to duration of infection. Radiology. https://doi. org/10.1148/radiol.2020200463

Benefits of Drones (2020) Covid-19 lockdown: authorities rely on drone eye to maintain vigil. https://economictimes.indiatimes .com/news/politics-and-nation/covid-19lockdownauthoritie s-rely-on-drone-eye-to-maintain-vigil/articleshow/75112745. cms. Accessed 26 Apr 2020

Biomedical waste Regulations (2020) Handling COVID-19 biomedical waste: cpcb releases guidelines. https://india.mongabay. com/2020/03/pollution-watchdog-releases-guidelinestohandleco vid-19-biomedical-waste/. Accessed 7 Apr 2020

Bharat Biotech vaccine (2020) Bharat biotech-vaccines, bio-therapeutics manufacturer in India. https://www.bharatbiotech.com/. Accessed 26 July 2020

British Broadcasting Council (BBC) (2020) Will Covid-19 have a lasting impact on the environment? https://www.bbc.com/futur e/article/20200326-covid-19-the-impactofcoronaviruson-theenvironment. Accessed 7 Apr 2020

Brooks SK, Webster RK, Smith LE, Woodland L, Wessely S, Greenberg N, Rubin GJ (2020) The psychological impact of quarantine and how to reduce it: rapid review of the evidence. The Lancet 395(10227):912-920. https://doi.org/10.1016/s0140 $-6736(20) 30460-8$

Brosch T, Tam R (2013) Manifold learning of brain MRIs by deep learning. Medical Image Computing and computer-assisted intervention-MICCAI 2013. Lecture Notes in Comput Sci (LNCS) 8150:633-640. https://doi.org/10.1007/978-3-642-40763-5_78

Carlos WG, Cruz CSD, Cao B, Pasnick S, Jamil S (2020) Novel Wuhan (2019-nCoV) coronavirus. Am J Respir Crit Care Med 201(4):78. https://doi.org/10.1164/rccm.2014p7

CanSino vaccine, 2020. China allows limited use of COVID-19 vaccine CanSino for their military after clinical trials shows its effectiveness. https://www.firstpost.com/health/china-allowslimited-usecovid-19-vaccine-cansino-military-clinical-trials-shows-effec tiveness-8544391.html. Accessed 26 July 2020

Central and Eastern Europe Legalblog (2020) Poland launches an official tracking app. https://www.ceelegalblog.com/2020/04/covid -19-poland-launches-an-official-trackingapp/. Accessed 21 July 2020

Centers for Disease Control and Prevention (2005) Interventions for community containment. https://www.cdc.gov/sars/guidance/dquarantine/app1.html. Accessed 7 Apr 2020

Centres for Disease Control and Prevention (2020) Image of coronavirus with spike protein. https://www.cdc.gov/media/subtopic/ images.htm. Accessed 26 Apr 2020

Cetron M, Landwirth J (2005) Public health and ethical considerations in planning for quarantine. Yale J Biol Med 78(5):329-334 (PMCID: PMC2259156)

Chang D, Lin M, Wei L, Xie L, Zhu G, Cruz CSD, Sharma L (2020) Epidemiologic and clinical characteristics of novel coronavirus infections involving 13 patients outside Wuhan, China. JAMA 323(11):1092-1093. https://doi.org/10.1001/jama.2020.1623

Chen H, Guo J, Wang C, Luo F, Yu X, Zhang W, Li J, Zhao D, Xu D, Gong Q, Liao J, Yang H, Hou W, Zhang Y (2020) Clinical characteristics and intrauterine vertical transmission potential of COVID-19 infection in nine pregnant women: a retrospective review of medical records. The Lancet 395(10226):809-815. https://doi.org/10.1016/s0140-6736(20)30360-3

Cheng Y, Wang F, Zhang P, Hu J (2016) Risk prediction with electronic health records: a deep learning approach. In: Proceedings of the 2016 SIAM International Conference on Data Mining. Society for Industrial and Applied Mathematics, pp 432-440. https://doi. org/10.1137/1.9781611974348.49

Ching T, Himmelstein DS, Beaulieu-Jones BK, Kalinin AA, Do BT, Way GP, Ferrero E, Agapow P-M, Zietz M, Hoffman MM, Xie W, Rosen GL, Lengerich BJ, Israeli J, Lanchantin J, Woloszynek S, Carpenter AE, Shrikumar A, Xu J, Cofer EM, Lavender CA, Turaga SC, Alexandari AM, Lu Z, Harris DJ, Decaprio D, Qi Y, Kundaje A, Peng Y, Wiley LK, Segler MHS, Boca SM, Swamidass SJ, Huang A, Gitter A, Greene CS (2018) Opportunities and obstacles for deep learning in biology and medicine. J R Soc Interface 15(141):20170387. https://doi.org/10.1098/ rsif.2017.0387

Chu CM (2004) Role of lopinavir/ritonavir in the treatment of SARS: initial virological and clinical findings. Thorax 59(3):252-256. https://doi.org/10.1136/thorax.2003.012658

Computer Aided E-learning (CAE) (2020) COVID-19 virus: changes in education. https://www.cae.net/covid-19-virus-changes-in-educa tion/. Accessed 7 Apri 2020

Covid Watch (2020) Official site of COVID-19 watch app. https://www. covid-watch.org/. Accessed 21 July 2020

COVID-19 SmartPhone Applications (2020) Top 10 popular smartphone apps to track Covid-19. https://www.geospatialworld.net/ blogs/popular-apps-covid-19/. Accessed 21 July 2020

Cvetkovic RS, Goa KL (2003) Lopinavir/Ritonavir. Drugs 63:769-802. https://doi.org/10.2165/00003495-200363080-00004

Drone Technologies (2020) World Economic Forum Beijing, 3 ways China is using drones to fight coronavirus. https://www.wefor um.org/agenda/2020/03/three-ways-china-is-using-drones-tofight-coronavirus/

Drop in production of essential goods (2020) Due to coronavirus production of essential goods runs row as manufacturers face lockdown hurdles. https://www.bloombergquint.com/coronaviru s-outbreak/coronavirus-productionofessential-goods-runs-lowas-manufacturers-face-lockdown-hurdles. Accessed 7 Apr 2020

Early warning (2020) Kidney is an early warning sign for severe COVID-19 cases. https://healthcarein-europe.com/en/news/ kidney-an-early-warning-sign-for-severe-covid-19-cases.html. Accessed 22 July 2020

Effects of water pollution (2019) Water pollution: an introduction to causes, effects, solutions. https://www.explainthatstuff.com/water pollution.html. Accessed 26 April 2020 
Elavarasan RM, Pugazhendhi R (2020) Restructured society and environment: a review on potential technological strategies to control the COVID-19 pandemic. Sci Total Environ 725:138858. https ://doi.org/10.1016/j.scitotenv.2020.138858

Esteva A, Kuprel B, Novoa RA, Ko J, Swetter SM, Blau HM, Thrun S (2017) Dermatologist-level classification of skin cancer with deep neural networks. Nature 542:115-118. https://doi. org/10.1038/nature21056

Estrada MAR (2020) The uses of drones in case of massive epidemics contagious diseases relief humanitarian aid: Wuhan-COVID-19 Crisis. SSRN Electron J. https://doi.org/10.2139/ssrn.3546547

Fakoor R, Ladhak F, Nazi A, Huber M (2013). Using deep learning to enhance cancer diagnosis and classification. In: Proceedings of the International Conference on Machine Learning (ICML), 28, New York, USA: ACM

Food and Drug Administration (FDA) (2020) Donate COVID-19 Plasma. https://www.fda.gov/emergency-preparedness-and-respo nse/coronavirus-disease-2019covid-19/donate-covid-19-plasma. Accessed 26 July 2020

Freedom of animals (2020) Urban wildlife spotting during COVID 19 lockdown. https://www.thehindu.com/sci-tech/energy-and-envir onment/covid-19-lockdownnotallnews-of-urban-wildlife-spott ing-is-factual/article31228052.ece. Accessed 7 Apr 2020

Furuta Y, Gowen BB, Takahashi K, Shiraki K, Smee DF, Barnard DL (2013) Favipiravir (T-705), a novel viral RNA polymerase inhibitor. Antiviral Res 100(2):446-454. https://doi.org/10.1016/j.antiv iral.2013.09.015

Gao J, Tian Z, Yang X (2020) Breakthrough: chloroquine phosphate has shown apparent efficacy in treatment of COVID-19 associated pneumonia in clinical studies. BioSci Trends 14(1):72-73. https://doi.org/10.5582/bst.2020.01047

Gautret P, Lagier J-C, Parola P, Hoang VT, Meddeb L, Mailhe M, Doudier B, Courjon J, Giordanengo V, Vieira VE, Dupont HT, Honoré S, Colson P, Chabrière E, Scola BL, Rolain J-M, Brouqui P, Raoult D (2020) Hydroxychloroquine and azithromycin as a treatment of COVID-19: results of an open-label non-randomized clinical trial. Int J Antimicrob Agents. https://doi.org/10.1016/j. ijantimicag.2020.105949

Geospatial World (2020) Top Indian apps to fight COVID-19. https:// www.geospatialworld.net/blogs/top-indian-apps-to-fight-covid $-19 /$. Accessed 21 July 2020

Gizbot (2020) Apps for COVID-19 prevention and control in India: features explained. https://www.gizbot.com/apps/features/appsfor-covid-19-prevention-and-control-in-indiafeatures-explained/ articlecontent-pf116871-067561.html. Accessed 21 July 2020

Goh KT, Chew SK (2006) Epidemiology of emerging infectious diseases in Singapore, with special reference to SARS. Popul Dyn Infect Dis Asia. https://doi.org/10.1142/9789812773395_0015

Golden EB, Cho H-Y, Hofman FM, Louie SG, Schönthal AH, Chen TC (2015) Quinoline-based antimalarial drugs: a novel class of autophagy inhibitors. Neurosurg Focus 38(3):E12. https://doi. org/10.3171/2014.12.focus 14748

Goldhill DH, Velthuis AJWT, Fletcher RA, Langat P, Zambon M, Lackenby A et al (2018) The mechanism of resistance to favipiravir in influenza. Proc Natl Acad Sci 115(45):11613-11618. https://doi.org/10.1073/pnas.1811345115

Guo Y-R, Cao Q-D, Hong Z-S, Tan Y-Y, Chen S-D, Jin H-J, Tan K-S, Wang DY, Yan Y (2020) The origin, transmission and clinical therapies on coronavirus disease 2019 (COVID-19) outbreakan update on the status. Mil Med Res 7(11):1-10. https://doi. org/10.1186/s40779-020-00240-0

Guidelines for Waste Disposal (2020) Guidelines issued for handling wastes generated during COVID-19 Patients Treatment. https:// swachhindia.ndtv.com/guidelines-issued-for-handling-of-waste -generated-during-covid-19-patients-treatment-43734/. Accessed 28 July 2020
Hegde V, Kulkarni R, Ajantha G (2007) Biomedical waste management. J Oral Maxillofac Pathol 11(1):5-9. https://doi. org/10.4103/0973-029x.33955

Hinton G (2018) Deep learning-a technology with the potential to transform health Care. JAMA 320(11):1101-1102. https://doi. org/10.1001/jama.2018.11100

Ideas For India (2020) Covid-19: Online classes and the digital divide. https://www.ideasforindia.in/topics/poverty-inequality/covid-19online-classesandthedigital-divide-during-the-times-of-coron a1.html. Accessed 7 Apr 2020

Impact on water bodies (2020) How is COVID-19 impacting the environment around us? https://www.investindia.gov.in/team-india -blogs/howcovid-19impacting-environment-around-us. Accessed 26 Apr 2020

Immuni (2020) Official site of Immuni app. https://www.immuni.itali a.it/. Accessed 21 July 2020

Impact of lockdown in China (2020) https://time.com/5796425/china -coronaviruslockdown/. Accessed 13 Apr 2020

Improvement of air quality (2020) India savors a rare upside to coronavirus: clean air. https://www.nytimes.com/2020/04/08/world /asia/india-pollution-coronavirus.html. Accessed 26 July 2020

Increase of online usage (2020) Are gamers breaking the internet during quarantine? https://towardsdatascience.com/are-gamer s-breaking-the-internet-during-quarantine- 176fed9fa83d. Accessed 27 Apr 2020

India's COVID-19 RO value (2020) India's Covid-19 R0 drops down. https://theprint.in/science/indias-covid-19-r0-down-to1-36-now- 25000-cases-by-april-end-at-this-rate-ims-scientist/405877/. Accessed 26 Apr 2020

Inovio vaccine (2020) Inovio Covid-19 vaccine shows promise in early-stage trial. https://www.clinicaltrialsarena.com/news/inovi o-covid-19-vaccine-data/.Accessed 26 July 2020

Javaid M, Haleem A, Vaishya R, Bahl S, Suman R, Vaish A (2020) Industry 40 technologies and their applications in fighting COVID-19 pandemic. Diabetes Metab Syndr Clin Res Rev 14(4):419-422. https://doi.org/10.1016/j.dsx.2020.04.032

Jefferson T, Jones M, Doshi P, Spencer EA, Onakpoya I, Heneghan CJ (2014) Oseltamivir for influenza in adults and children: systematic review of clinical study reports and summary of regulatory comments. BMJ 348:g2545. https://doi.org/10.1136/bmj.g2545

Jindal V, Birjandtalab J, Pouyan MB, Nourani M (2016) An adaptive deep learning approach for PPG-based identification. In: 2016 38th Annual International Conference of the IEEE Engineering in Medicine and Biology Society (EMBC), pp 6401-6404.https ://doi.org/10.1109/embc.2016.7592193

Lan L, Xu D, Ye G, Xia C, Wang S, Li Y, Xu H (2020) Positive RTPCR test results in patients recovered from COVID-19. JAMA 323(15):1502-1503. https://doi.org/10.1001/jama.2020.2783

Lasko TA, Denny JC, Levy MA (2013) Computational phenotype discovery using unsupervised feature learning over noisy, sparse, and irregular clinical data. PLoS ONE 8(6):e66341. https://doi.org/10.1371/journal.pone.0066341

Lewnard JA, Lo NC (2020) Scientific and ethical basis for socialdistancing interventions against COVID-19. Lancet Infect Dis. https://doi.org/10.1016/S1473-3099(20)30190-0

Li Q, Guan X, Wu P, Wang X, Zhou L, Tong Y, Ren R, Leung KS, Lau EH, Wong JY, Xing X, Xiang N, Wu Y, Li C, Chen Q, Li D, Liu T, Zhao J, Liu M, Tu W, Chen C, Jin L, Yang R, Wang Q, Zhou S, Wang R, Liu H, Luo Y, Liu Y, Shao G, Li H, Tao Z, Yang Y, Deng Z, Liu B, Ma Z, Zhang Y, Shi G, Lam TT, Wu JT, Gao GF, Cowling BJ, Yang B, Leung GM, Feng Z (2020) Early transmission dynamics in Wuhan, China, of novel coronavirus-infected pneumonia. N Engl J Med 382:1199-1207. https://doi.org/10.1056/nejmoa2001316

Liang Z, Zhang G, Huang JX, Hu QV (2014) Deep learning for healthcare decision making with EMRs. In: 2014 IEEE

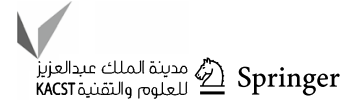


International Conference on Bioinformatics and Biomedicine (BIBM), Belfast, 556-559. https://doi.org/10.1109/ bibm.2014.6999219

Liu S, Liu S, Cai W, Pujol S, Kikinis R, Feng D (2014) Early diagnosis of Alzheimer's disease with deep learning. In: 2014 IEEE 11th International Symposium on Biomedical Imaging (ISBI), Beijing, pp 1015-1018. https://doi.org/10.1109/ isbi.2014.6868045

Liu Y, Gayle AA, Wilder-Smith A, Rocklöv J (2020a) The reproductive number of COVID-19 is higher compared to SARS coronavirus. J Travel Med 27(2):taaa01. https://doi.org/10.1093/ jtm/taaa021

Liu S, Yang L, Zhang C, Xiang Y-T, Liu Z, Hu S, Zhang B (2020b) Online mental health services in China during the COVID19 outbreak. Lancet Psychiatry 7(4):e17-18. https://doi. org/10.1016/s2215-0366(20)30077-8

Livemint (2020) Aarogya Setu and the value of syndromic surveillance. https://www.livemint.com/opinion/columns/aarogya-setuand-the-value-of-syndromicsurveillance-11589304017285.html. Accessed 21 July 2020

Lu H (2020) Drug treatment options for the 2019-new coronavirus (2019-nCoV). BioSci Trends 14(1):69-71. https://doi. org/10.5582/bst.2020.01020

Lyons J, Dehzangi A, Heffernan R, Sharma A, Paliwal K, Sattar A, Zhou Y, Yang Y (2014) Predicting backbone C $\alpha$ angles and dihedrals from protein sequences by stacked sparse auto-encoder deep neural network. J Comput Chem 35(28):2040-2046. https ://doi.org/10.1002/jcc.23718

Machine Learning in Hellathcare (2020) How to fight COVID-19 with machine learning. https://towardsdatascience.com/fight-covid -19-with-machine-learning-1d1106192d84?gi=3988c2c9ca1a. Accessed 7 Apr 2020

Management during Pandemic (2020) Covid-19: 8 ways in which technology helps pandemic management. https://cio.economictimes. indiatimes.com/news/next-gen-technologies/covid-19-8-waysi n-which-technology-helps-pandemic-management/75139759. Accessed 21 July 2020

Mak K-K, Pichika MR (2019) Artificial intelligence in drug development: present status and future prospects. Drug Discov Today 24(3):773-780. https://doi.org/10.1016/j.drudis.2018.11.014

McCall B (2020) COVID-19 and artificial intelligence: protecting health-care workers and curbing the spread. Lancet Digit Health 2(4), e166-e167. https://doi.org/10.1016/s2589-7500(20)30054-6

Mcquade B, Blair M (2015) Influenza treatment with oseltamivir outside of labeled recommendations. Am J Health-Syst Pharm 72(2): 112-116. https://doi.org/10.2146/ajhp140390

Miotto R, Wang F, Wang S, Jiang X, Dudley JT (2018) Deep learning for healthcare: review, opportunities and challenges. Brief Bioinform 19(6):1236-1246. https://doi.org/10.1093/bib/bbx044

Mohammed MN, Hazairin NA, Syamsudin H, Al-Zubaidi S, Sairah AK, Mustapha S, Yusuf E (2020) 2019 novel coronavirus disease (Covid-19): detection and diagnosis system using IoT based smart glasses. Int J Adv Sci Technol 29(7):954-960

Natural effect on this pandemic (2020) The pandemic is turning the natural world upside down. https://www.theatlantic.com/scien ce/archive/2020/04/coronavirus-pandemicearthpollution-noise /609316/. Accessed 26 Apr 2020

Natural remedies to treat swine flu (2016) Kabasuraneer Choornam (Swine Flu). https://www.nhp.gov.in/swineflu_mtl. Accessed 26 Apr 2020

Nguyen P, Tran T, Wickramasinghe N, Venkatesh S (2016) A Convolutional net for medical records. IEEE J Biomed Health Inf 21(1):22-30. https://doi.org/10.1109/jbhi.2016.2633963

Omar SZ, Daud A, Hassan MS, Bolong J, Teimmouri M (2014) Children internet usage: opportunities for self development.
Proc Soc Behav Sci 155:75-80. https://doi.org/10.1016/j.sbspr o.2014.10.259

Onder G, Rezza G, Brusaferro S (2020) Case-fatality rate and characteristics of patients dying in relation to COVID-19 in Italy. JAMA. https://doi.org/10.1001/jama.2020.4683

Online Education (2020) Online learning gets its moment due to COVID-19 pandemic: Here's how education will change. https ://www.zdnet.com/article/online-learning-gets-itsmomentdue-tocovid-19pandemic-heres-how-education-will-change/. Accessed 7 Apr 2020

Outbreak of COVID-19 (2020) The epidemiological characteristics of an outbreak of 2019 novel Coronavirus diseases (COVID19)-China, 2020. China CDC (Center for Disease Control and Prevention) Wkly 2(8):113-122

Pan F, Ye T, Sun P, Gui S, Liang B, Li L, Zheng D, Wang J, Hesketh RL, Yang L, Zheng C (2020) Time course of lung changes on chest CT during recovery from 2019 Novel Coronavirus (COVID-19) Pneumonia. Radiology. https://doi.org/10.1148/ radiol.2020200370

Polluted cities (2019) Delhi struggles to breathe but not even in top 10 polluted Indian cities. https://www.indiatoday.in/diu/story/delhi -not-the-most-polluted-city-in-india-up-airmorepoisonous-16157 39-2019-11-05. Accessed 7 Apr 2020

Prasoon A, Petersen K, Igel C, Lauze F, Dam E, Nielsen M (2013) Deep feature learning for knee cartilage segmentation using a triplanar convolutional neural network. In: Medical Image Computing and Computer-Assisted Intervention-MICCAI 2013. Lecture Notes in Computer Science (LNCS), 8150, 246-253. Springer, Berlin, Heidelberg. https://doi.org/10.1007/978-3642-40763-5_3

Prem K, Liu Y, Russell TW, Kucharski AJ, Eggo RM, Davies N, Jit M, Klepac P, Flasche S, Clifford S, Pearson CAB, Munday JD, Abbott S, Gibbs H, Rosello A, Quilty BJ, Jombart T, Sun F, Diamond C, Gimma A, Zandvoort KV, Funk S, Jarvis CI, Edmunds WJ, Bosse NI, Hellewell J (2020) The effect of control strategies to reduce social mixing on outcomes of the COVID-19 epidemic in Wuhan, China: a modelling study. Lancet Public Health. https ://doi.org/10.1016/s2468-2667(20)30073-6

Predetermining Artificial Intelligence (2020) Artificial intelligence against COVID-19: an early review. https://towardsdatascie nce.com/artificial-intelligence-against-covid-19-anearly-revie w-92a8360edaba. Accessed 7 Apr 2020

Qamar MTU, Alqahtani SM, Alamri MA, Chen LL (2020) Structural basis of SARSCoV2 3CLpro and anti-COVID-19 drug discovery from medicinal plants. J Pharm Anal. https://doi.org/10.1016/j. jpha.2020.03.009

Rapid increase in web usage (2020) Web browsing has increased by over 70 percent amid Covid-19. https://www.thehindubusines sline.com/info-tech/socialmedia/web-browsinghasincreased -by-over-70-per-cent-amid-covid-19report/article31174107.ece\#. Accessed 7 Apr 2020

Razavian N, Marcus J, Sontag D (2016) Multi-task prediction of disease onsets from longitudinal laboratory tests. In: Presented at the Machine Learning for Healthcare Conference, Los Angeles, CA, PMLR 56, pp 73-100

Remedy given by Siddha field (2020) COVID-19: people throng to buy Siddha drug kabasuraneer choornam. https://www.thehindu.com/ news/cities/chennai/covid-19peoplethrong-to-buy-siddhadrug -kabasura-kudineer/article31225180.ece. Accessed 7 April 2020

Research updates on vaccine (2020) COVID-19 vaccine: 3 candidates are at final trials, show 'good results'. https://www.livemint. com/news/india/coronavirus-update-when-will-we-have-a-covid -19vaccine-11595585331811.html. Accessed 26 July 262020

Riou B, Barriot P, Rimailho A, Baud FJ (1988) Treatment of severe chloroquine poisoning. N Engl J Med 318(1):1-6. https://doi. org/10.1056/nejm198801073180101 
Rocklöv J, Sjödin H (2020) High population densities catalyze the spread of COVID-19. J Travel Med. https://doi.org/10.1093/jtm/ taaa038

Rothe C, Schunk M, Sothmann P, Bretzel G, Froeschl G, Wallrauch C, Zimmer T, Thiel V, Janke C, Guggemos W, Seilmaier M, Drosten C, Vollmar P, Zwirglmaier K, Zange S, Wölfel R, Hoelscher M (2019nCoV) Transmission of $2019 \mathrm{nCoV}$ infection from an asymptomatic contact in Germany. N Engl J Med 382(10):970971. https://doi.org/10.1056/nejmc2001468

Saravanan J, Devasia N, Gopalasatheeskumar K, SanishDevan V, ThangaKokila K, Sanjay M (2018) Anti-inflammatory, antipyretic and antibacterial study of kabasurakudineerchoornam. Int J Curr Adv Res 7(2):9992-9997

Savarino A, Boelaert JR, Cassone A, Majori G, Cauda R (2003) Effects of chloroquine on viral infections: an old drug against today's diseases. Lancet Infect Dis 3(11):722-727. https://doi. org/10.1016/s1473-3099(03)00806-5

Science Daily (2020a) The COVID-19 coronavirus epidemic has a natural origin. https://www.sciencedaily.com/releases/2020/03/20031 7175442.htm. Accessed 7 Apr 2020

Science Daily (2020b) How effective is quarantine alone or in combination with other public health measures to control coronavirus (COVID-19)? https://www.sciencedaily.com/relea ses/2020/04/200408133253.htm. Accessed 13 Apr 2020

Sinovac vaccine (2020) China's Sinovac Biotech begins phase 3 trials of coronavirus vaccine candidate in Brazil. https://www.hospi medica.com/covid-19/articles/294783405/chinassinovac-biote ch-begins-phase-3-trials-of-coronavirus-vaccine-candidate-inbrazil.html. Accessed 26 July 2020

Social distancing in UK (2020) UK government plans to start social distancing after new model points to 260000 potential deaths. https://www.bmj.com/content/368/bmj.m1089/rapidrespo nses?int_source $=$ trendmd\&int_mediu $\mathrm{m}=\mathrm{cpc} \&$ int_campa ign=usage-042019. Accessed 7 Apr 2020

Sohrabi C, Alsafi Z, O'neill N, Khan M, Kerwan A, Al-Jabir A, Iosifidis C, Agha R (2020) World Health Organization declares global emergency: A review of the 2019 novel coronavirus (COVID-19). Int J Surg 76:71-76. https://doi.org/10.1016/j. ijsu.2020.02.034

Spychalski P, Błażyńska-Spychalska A, Kobiela J (2020) Estimating case fatality rates of COVID-19. Lancet Infect Dis. https://doi. org/10.1016/s1473-3099(20)30246-2

Statistical Usage (2020) Internet usage in India-statistics \& facts. https://www.statista.com/topics/2157/internet-usage-in-india/. Accessed 22 July 2020

Singh RP, Javaid M, Haleem A, Suman R (2020) Internet of things (IoT) applications to fight against COVID-19 pandemic. Diabetes Metab Syndr Clin Res Rev 14(4):521-524. https://doi. org/10.1016/j.dsx.2020.04.041

Switching Healtcare (2018) What is deep learning and how will it change healthcare?. https://healthitanalytics.com/features/whatis-deep-learningand-howwill-it-changehealthcare. Accessed 7 Apr 2020

Tchesnokov E, Feng J, Porter D, Götte M (2019) Mechanism of inhibition of ebola virus RNA-dependent RNA polymerase by remdesivir. Viruses 11(4):326. https://doi.org/10.3390/v11040326

Tracking Apps for COVID-19 (2020) How does the Aarogya Setu app work? https://www.thehindu.com/news/national/how-does-theaarogya-setu-appwork/article31532073.ece. Accessed 21 July 2020

Tsang K, Zhong NS (2003) SARS: pharmacotherapy. Respirology 8:S25-S30. https://doi.org/10.1046/j.14401843.2003.00525.x

Vincent MJ, Bergeron E, Benjannet S, Erickson BR, Rollin PE, Ksiazek TG, Seidah NG, Nichol ST (2005) Chloroquine is a potent inhibitor of SARS coronavirus infection and spread. Virol J 2(1):69. https://doi.org/10.1186/1743-422x-2-69
Wang M, Cao R, Zhang L, Yang X, Liu J, Xu M, Shi Z, Hu Z, Zhong W, Xiao G (2020a) Remdesivir and chloroquine effectively inhibit the recently emerged novel coronavirus (2019-nCoV) in vitro. Cell Res 30(3):269-271. https://doi.org/10.1038/s4142 2-020-0282-0

Wang C, Horby PW, Hayden FG, Gao GF (2020b) A novel coronavirus outbreak of global health concern. The Lancet 395(10223):470 473. https://doi.org/10.1016/s0140-6736(20)30185-9

Wang G, Zhang Y, Zhao J, Zhang J, Jiang F (2020c) Mitigate the effects of home confinement on children during the COVID-19 outbreak. The Lancet 395(10228):945-947. https://doi.org/10.1016/ s0140-6736(20)30547-x

Water quality improvement during lockdown (2020) COVID-19 lockdown: Health of Ganga and Yamuna river improves. https://www. indiawaterportal.org/articles/covid-19-lockdown-health-ganga and-yamunarivers-improves. Accessed 7 Apri 2020

Web safety for kids (2018) Internet safety (for Parents). https://kidsh ealth.org/en/parents/net-safety.html. Accessed 26 Apr 2020

Wilder-Smith A, Freedman DO (2020) Isolation, quarantine, social distancing and community containment: pivotal role for old-style public health measures in the novel coronavirus (2019-nCoV) outbreak. J Travel Med 27(2):taaa020. https://doi.org/10.1093/ jtm/taaa020

Wong YK, Yang J, He Y (2020) Caution and clarity required in the use of chloroquine for COVID-19. Lancet Rheumatol. https://doi. org/10.1016/s2665-9913(20)30093-x

Worldometers (2020a) Coronavirus cases. https://www.worldomete rs.info/coronavirus/. Accessed 7 Apr 2020

Worldometers (2020b) Daily new cases in China due to COVID-19. https://www.worldometers.info/coronavirus/country/china/. Accessed 13 Apr 2020

World Health Organization (WHO) (2020a) Modes of transmission of virus causing COVID-19: implications for IPC precautions recommendations. https://www.who.int/newsroom/commentari es/detail/modes-of-transmission-ofviruscausing-covid-19-impli cationsfor-ipc-precaution-recommendations. Accessed 7 Apr 2020

World Health Organization (WHO) (2020b) Coronavirus disease (COVID-19) - events as they happen. https://www.who.int/emerg encies/diseases/novel-coronavirus-2019/eventsasthey-happen. Accessed 7 Apr 2020

World Health Organization (WHO) (2020c) Prevention and control of COVID-19 in prisons and other places of detention. https:// www.euro.who.int/en/healthtopics/healthemergencies/coron avirus-covid-19/novel-coronavirus-2019-ncovtechnicalguidanc e/coronavirus-disease-covid-19-outbreak-technical-guidanceeu rope/preventionand-control-of-covid-19-in-prisons-and-other -places-of-detention. Accessed 26 Apr 2020

World Health Organization (WHO) (2020d) Draft landscape of COVID-19 candidate vaccines. https://www.who.int/publicatio $\mathrm{ns} / \mathrm{m} /$ item/draft-landscape-of-covid-19-candidate-vaccines. Accessed 26 July 2020

Xiao C (2020) A novel approach of consultation on 2019 novel coronavirus (COVID19) related psychological and mental problems: structured letter therapy. Psychiatry Investig 17(2):175-176. https://doi.org/10.30773/pi.2020.0047

Yoo J-H (2019) The fight against the 2019-nCoV outbreak: an arduous march has just begun. J Korean Med Sci 35(4):e56. https://doi. org/10.3346/jkms.2020.35.e56

Zhao S, Lin Q, Ran J, Musa SS, Yang G, Wang W, Lou Y, Gao D, Yang L, He D, Wang MH (2020) Preliminary estimation of the basic reproduction number of novel coronavirus (2019-nCoV) in China, from 2019 to 2020: a data-driven analysis in the early phase of the outbreak. Int J Infect Dis 92:214-217. https://doi. org/10.1016/j.ijid.2020.01.050

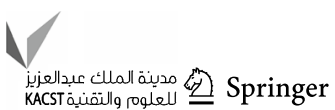


Zhou F, Yu T, Du R, Fan G, Liu Y, Liu Z, Xiang J, Wang Y, Song B, Gu X, Guan L, Wei Y, Li H, Wu X, Xu J, Tu S, Zhang Y, Chen $\mathrm{H}$, Cao B (2020) Clinical course and risk factors for mortality of adult inpatients with COVID-19 in Wuhan, China: a retrospective cohort study. The Lancet 395(10229):1054-1062. https:// doi.org/10.1016/s0140-6736(20)30566-3
Zhu J, Pande A, Mohapatra P, Han JJ (2015) Using deep learning for energy expenditure estimation with wearable sensors. In: 2015 17th International Conference on E-health Networking, Application \& Services (HealthCom), Boston, MA, pp 501-506. https:// doi.org/10.1109/healthcom.2015.7454554 